\title{
ALL IN THE FAMILY: THE INFLUENCE OF SOCIAL NETWORKS ON DISPUTE PROCESSING (A CASE STUDY OF A DEVELOPING ECONOMY)
}

\author{
Manuel A. Gómez*
}

\section{TABLE OF CONTENTS}

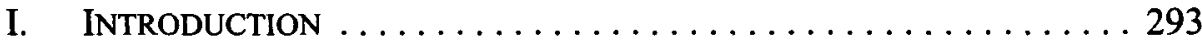

Why Explore the Business Sector . . . . . . . . . . . . 295

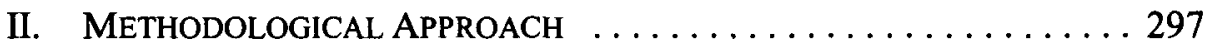

III. The COMPETING PARADIGMS IN THE STUDY OF DisPUTE PROCESSING AND PRocEdURAL CHOICES ............. 299

A. Modern Societies, Primitive Societies: A Real Dichotomy? . . . 299

B. Theoretical Paradigms and Dispute Processing . . . . . . 302

C. The Social Networks' Paradigm ................. 308

* Assistant Professor, Florida International University College of Law. I wish to express my gratitude to Deborah R. Hensler, Rogelio Pérez-Perdomo, and Lawrence M. Friedman for their valuable feedback and extensive comments throughout the process of writing this Article. I owe special thanks to the Center for Latin American Studies at Stanford University, the Stanford Center for Conflict and Negotiation (SCCN), and the members of the Class of 2002 Fellowship in Dispute Resolution from Stanford Law School for their generous financial support during different stages of this research. I also appreciate those who agreed to participate in the more than seventy interviews that I conducted in Venezuela from 2002 through 2006 for their candidness and generosity of time. This Article is based on the research conducted for a doctoral dissertation submitted by the author to Stanford University in January 2007. This Article received the 2007 Richard S. Goldsmith Award for Best paper on Dispute Resolution at Stanford University and the 2007 Scholarly Writing Award of the Section on Venezuelan Studies at the Latin American Studies Association (LASA). 
IV. All In The Family: Social StRUCtURE, NETWORKS AND THE

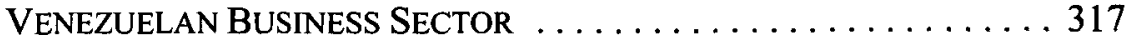

A. Black Gold: The Impact of an Oil-based Economy on the Venezuelan Society .............. 317

B. Friends Go First: The Importance of the

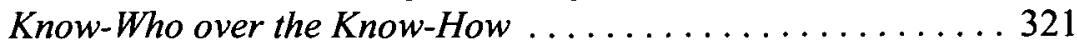

V. FROM THE TRIBES TO THE JUDICIAL REVOLUTION:

THE PERSISTENT INFLUENCE OF SOCIAL NETWORKS IN THE VENEZUELAN COURTS . . ................... 324

A. Demystifying Judicial Inefficiency ............... 324

The Efficiency of "Malfunctioning" Courts . . . . . . . . 327

B. Dispute Processing, Networks and the Courts:

From the Tribes to the Judicial Revolution of the Twenty-First Century ...................... 331

VI. Thanks BUt No Thanks: THE MOdest ACCEPTANCE OF ADR PROVIDING ORGANIZATIONS IN VENEZUELA . . . . . . . 339

A. ADR and Judicial Reform Agendas: Shooting First . . . . . 340

B. ADR and the Private Sector . ................ 342

C. Thanks, But No Thanks .................... 348

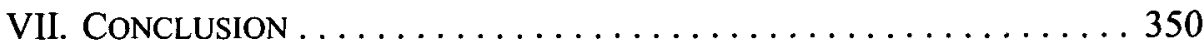




\section{INTRODUCTION}

This Article constitutes an effort to describe the influence of social networks on how individuals choose to process their legal disputes. The objective is to explain how social connections shape the ways in which conflict is processed within formal institutions. Using the social context in which the Venezuelan business sector operates as a framework, this research tries to draw a real life picture of how dispute processing occurs in society, which in turn, is important in understanding how different systems of social control can function.

For many years, scholars from several social science disciplines have explored the ways in which the processing of legal disputes occurs in society. Anthropologists, for example, have offered a deep and highly contextualized description of the social and cultural dynamics that take place in different primitive or rural environments in order to explain how the larger social structure is affected. Social psychologists, have instead devoted their attention to the narrow sphere of individual behavior, focusing on the reaction of individuals to social processes, but often from a de-contextualized perspective. In contrast, legal scholars have turned most of their interest to formal and official institutions, with special emphasis on the importance of statesponsored enforcement mechanisms. Even though mainstream legal scholars have also expressed an interest in exploring the role of legal actors, their approach is usually limited to a legal centralistic one.

Legal scholars have viewed official legal institutions and their normative framework as society's most important component, responsible for the achievement of social order, progress, and economic efficiency. During the last two decades, multilateral institutions have embarked on an enormous enterprise to propagate this fairytale idea, but have largely ignored the context and the cultural nuances that distinguish the different countries for which these formulas are geared.

An example of this has occurred with the implementation of Alternative Dispute Resolution (ADR) mechanisms in Latin America. The vast majority of the judicial reform initiatives proposed by the World Bank and the InterAmerican Development Bank in Latin America included the promotion of $\mathrm{ADR}$ as a way to attract foreign private investors to the region and as a remedy for the perceived congestion and malfunctioning of the courts. ADR processes were believed to work well in developed countries (namely, the United States) 
for handling disputes at many different levels; therefore, reform advocates viewed these processes as a panacea for the region.

Latin American governments felt compelled to implement policies regarding $A D R$. At the same time, a number of private corporations and chambers of commerce began funding initiatives to create ADR centers to serve mainly the business community. It was believed that by helping this sector, governments were creating favorable conditions to attract foreign investment, which considered the existence of modern and transparent dispute processing institutions a priority.

Despite the large investment in ADR institutions and the numerous campaigns geared to highlight the benefits of the modern, cost-efficient, and transparent mechanisms now available to business disputants, members of the business community did not embrace these new mechanisms. Business parties continued processing most of their disputes in the same ways they did before the judicial reform craze. Instead of the new institutionalized ADR, informal conciliatory processes channeled through the existing social networks were widely utilized. Some close-knit communities (e.g., the diamond industry) continued employing the same traditional ways of dealing with disputes among its members, employing the help of their dense social networks; even the official courts were often utilized by business disputants with their social connections in mind.

As is known from previous research, ${ }^{1}$ disputants in general contemplate a wide array of procedural choices. Official institutions are just one of their alternatives, but little has been done in order to present a comparative view ${ }^{2}$ about the different avenues that are available to disputants in light of their social and cultural context. Such an analysis would definitely improve the understanding about how the dispute processing business of a given society-or particular sector within a society-is distributed. ${ }^{3}$

'See, e.g., Richard Abel, A Comparative Theory of Dispute Institutions in Society, 8 LAW \& SOC'Y REV. 217, 230 (1973); William L.F. Felstiner, Influences of Social Organization on Dispute Processing, 9 LAW \& SoC'Y REV. 63, 64 (1974); Austin Sarat, Alternatives in Dispute Processing: Litigation in a Small Claims Court, 10 LAW \& SOC'Y REV. 339, 342 (1976).

${ }^{2}$ Sarat, supra note 1, at 342 ("[M]ost studies of litigation are not comparative, that is, they do not place litigation in the context of the full range of dispute processing alternatives which society provides. Few have inquired as to why disputants choose one alternative over others which might deal with their problem. ...").

${ }^{3} I d$. at 341 ("Thus the choices which people make among dispute processing alternatives are important in determining the way in which society's dispute processing business is 
Why Explore the Business Sector

To obtain a more complete picture of dispute processing activities in society, one cannot only study the courts, but must also expand his research to other levels of social organization and to the processes that take place on these other levels. Therefore, the study of procedural choices in the larger context is very important. In order to do such a study, one would have to take into account all the available choices (or, at least, the greatest possible array of choices) in a particular society. Such an effort would obviously require an enormous data collection task beyond the capabilities of an individual researcher.

A more limited, but by no means less important, feasible approach is to limit the scope of the research to a particular sector of a given society, explore the available options that are presented to individuals in that specific context and try to identify the factors that shape their procedural preferences. This way, a researcher could obtain a picture that is closer to reality, and would be able to explore what works, what does not, and why. The business sector is suitable for this approach for a number of reasons.

First, the business sector is usually an affluent segment of society whose members tend to have more access to resources and to innovation than other groups. As a result, business people encounter fewer barriers when accessing formal and informal dispute processing fora and mechanisms than do members of other segments of society. However, in their everyday life, business people have to circumvent many obstacles, and their exposure to dispute processing choices is generally broader than other groups' exposure.

Second, as a result of their interaction with other actors- both within and outside their environment-business people are in a constant process of learning new techniques to conduct their activities, adapting to other settings, and adopting different ways of dealing with difficulties that arise in the course of their business dealings.

Finally, the business sector has been the focus of several legal and judicial reform efforts (e.g., World Bank reform agendas) due to the belief that strengthening and devoting important resources to business will lead to greater economic welfare and to overall improved socioeconomic conditions. As a result, the business sector has been the test ground for new dispute processing 
techniques (namely, ADR). This is yet another reason to focus on this sector when exploring disputants' behavioral and procedural choices.

This Article, therefore, focuses on business disputes. I define business disputes broadly to mean potential legal conflicts in which a business has a stake or interest. Given this broad definition, business disputes are not necessarily of a commercial nature. For example, they can also relate to labor and intellectual property. I am not considering, however, disputes that involve public entities or the state even if the other party is a private business entity or individual business people. Each of these categories may have different features, and they are often processed in very different ways.

This Article addresses two interconnected research questions: which dispute processing systems are preferred, and why. I try to answer these questions through the subjective lens of Venezuelan business disputants. ${ }^{4}$ I do not aspire to draw generalizations or to derive some theory from my observations; my goal is simply to offer a description of how the social and cultural dynamics shape the ways in which individuals behave.

Although I have chosen to explore the business sector of Venezuela, my intention has not been to do a study only about how social networks influence the ways in which business disputes are dealt with in Venezuela. Rather, it is research about how the social, cultural, economic, and political dimensions of a given society (indeed, it could be any society) interplay with the existing social networks in affecting individuals' procedural choices. But, in order to correlate theory with reality, Venezuela is employed as a case study.

I believe that this approach represents a helpful way of understanding, generally, how dispute processing mechanisms are used in light of the existing institutions and other fora.

Studying the Venezuelan business context offers a tremendous opportunity to discover dispute processing choices in an environment that combines many features that are typically seen in technologically advanced, modern, and affluent societies and at the same time, discover some of the characteristics that socio-legal scholars attribute to societies considered to be primitive, indigenous, or traditional. This interesting contrast allows me to explore how

${ }^{4}$ See Robert M. Hayden \& Jill K. Anderson, On the Evaluation of Procedural Systems in Laboratory Experiments: A Critique of Thibaut and Walker, 3 LAW \& HUM. BEHAV. 21, 36 (1979). 
the different mechanisms of social control interact within a specific social and cultural context, and how the social network paradigm can facilitate its study.

This Article is divided into seven parts. Parts I and II offer an introduction to and a description of the methodological approach that constitutes the basis of this research. Part III addresses the conceptual and theoretical underpinnings of this Article. To this end, I offer a description of the traditional dichotomy that prevails in the socio-legal literature when describing different social structures and legal systems. In this part, I also contrast the different approaches used to explain dispute processing and offer the social networks paradigm as an analytical tool for explaining choices for dispute processing fora and mechanisms. Part IV describes the structure of Venezuelan society and its business sector, with special attention to the pervasiveness of social networks at several levels. Part V explains how social networks are relied upon by users of the official legal system, and how disputants have strong incentives to use the courts, in spite of the conventional wisdom that the judiciary is the least preferred forum because of its perceived malfunctioning. Part VI, further applies the social networks' paradigm to explain why business disputants in Venezuela have not embraced the recently promoted ADR centers and how they prefer to use mediation and arbitration outside these institutions. Finally, Part VII offers the conclusion.

\section{METHODOLOGICAL APPROACH}

The overarching strategy of the research that constitutes the basis of this Article has been a case study using different methods to collect, classify, and analyze the data that informs its substance.

In order to gain a broad but meaningful view of how social networks influence dispute processing choices for institutionalized mechanisms and fora by members of the Venezuelan business sector, I collected data on the two main areas of institutionalized business disputes-courts and ADR centers-that are available to parties in that country. ${ }^{5}$

$s$ The larger project, in which this Article is based, also focused on "non-institutionalized" processes, that is, those that take place outside state-sponsored institutions. I specifically addressed two forms of informal dispute processing that are available to business disputants in Venezuela: the use of shaming techniques by debt-collection agencies to enforce contracts, and the use of arbitration among non-Jewish diamond merchants to process the disputes arising from their dealings. The idea was to illustrate how social networks are equally relevant in the 
The majority of the data collected for this research were obtained from secondary sources in the form of administrative records and documents (judicial statistics on court usage, examination of official records and private databases alike) and from semi-structured interviews with at least seventy respondents who were selected because of their familiarity with the particular aspects of each case.

Several court officials, public and private administrators (such as judicial reform program managers and ADR program managers respectively), lawyers, and their clients (individual businesspeople and executives representing business entities of various sizes and natures) were the core of my research population. As for the business people and executives, most of them were domestic, as the majority of their business activity took place in Venezuela, but I also looked into foreign investors and to Venezuelans who conduct their activities in other jurisdictions.

Interviewees were selected-as it commonly happens when doing qualitative research - through a non-random purposive sampling technique; that is a deliberately chosen group of persons, settings, or events that possess certain characteristics or information that cannot be obtained from other choices. ${ }^{6}$

As I gained access to the databases of several business organizations and chambers of commerce, it was possible to get a comprehensive map of how the business community is organized in Venezuela, and most importantly, about the different relations that exist among its members. The lawyers who serve these people and organizations were also taken into account because they are usually the ones who make, or heavily influence, the decisions to use a particular forum or dispute processing method.

Most interviews were based on protocols prepared in advance. Even though my informants agreed without hesitation to participate in the study, I promised most of them that I would keep their identities confidential; this helped promote candor during our conversations. The majority of the interviews were conducted during my trips to Venezuela, face-to-face, with the

selection of mechanisms and fora for processing business disputes at the formal and informal levels. For a detailed discussion see Manuel A. Gómez, All in the Family (Jan. 2007) (unpublished J.S.D. dissertation, Stanford University, available at http://www.law.stanford. edu/publications/dissertations_theses/diss/MAGomez-dft07.pdf).

${ }^{6}$ Joseph A. Maxwell, Designing a Qualitative Study, in HANDBOOK OF APPLIED SOCIAL RESEARCH METHODS 87 (Leonard Bickman \& Debra J. Reg eds., 1998). 
interviewees, and only a relatively small number of interviews had to be conducted by phone or electronic mail in cases where some interviewees were in a different city or country.

Some of my interviewees agreed to meet me on more than one occasion, either for follow-up conversations or to talk about new issues that emerged after our initial encounters. The average interview lasted ninety minutes, and sometimes digital recordings were possible, but in general, I did not transcribe the conversations; rather, I used the recorded files to complete my notes or to confirm notions that were not clear when the conversation took place. When I was not able to record the interview, personal notes were taken; those notes were then organized and coded for further use during the writing process.

The field research was conducted during at least eight trips to Venezuela in the four years between the spring of 2002 and the summer of 2006. Because some trips were two or three months long, I was often able to organize data collection efforts with relatively little time pressure.

The methodological approach that I have selected for this project has some distinctive advantages. First, it has allowed me to obtain a deep and contextualized description of the social, cultural, and institutional environments in which business disputants interact. Second, it has made possible the gathering of data through different empirical methods. Finally, it has given me an opportunity to explore a social phenomenon in its real-life form and to analyze it from a sociological perspective in a way that has been generally overlooked by socio-legal scholars.

As for the limitations, perhaps the most important one, as in any case study, lies in the fact that this research is not representative, in the sense that one cannot infer frequencies or generalizations from it. Notwithstanding the limitations, the kind of qualitative research that I have selected seems to be the most appropriate given the type of research questions posed and the objectives that inform this research.

\section{The COMPETING PARADIGMS IN THE STUdY OF DisPUTE Processing AND PROCEDURAL ChOICES}

\section{A. Modern Societies, Primitive Societies: A Real Dichotomy?}

The efforts of socio-legal scholars in understanding how dispute processing systems work and how the social, cultural, economic, and political dimensions 
interact with each other have always focused on two polar opposite types of society, two contrasting realities that are perceived to embody different styles of procedures. ${ }^{7}$ On the one hand, there are the underdeveloped and traditional societies. In these, official courts and other basic institutions may exist, ${ }^{8}$ but the social, economic and political structure is largely dominated by (extended) families, cliques, groups, or clans that give way to the rise of strong social networks, which in turn influence how society operates, reinforce its cultural values, and most importantly, provide the conditions under which social conflict is handled. ${ }^{9}$

The normative system of these less-modern societies is basically defined by indigenous or local norms and the dispute processing institutions here tend to be undifferentiated. ${ }^{10}$ Also, legal norms are often intertwined with social norms; thus, frequently, the two are difficult to differentiate from one another. ${ }^{11}$

Compliance and enforcement are usually achieved through several forms of coercion such as shaming, gossiping, or threat of social isolation; and here, the political authorities tend to be the same as social ones (elders, wise men, chiefs). ${ }^{12}$ Ordinary members of these societies usually know and understand the normative system well enough, so that legal disputes can be usually handled face-to-face, with the direct involvement of the parties, and by taking into consideration their broader and often multiplex social relationships. ${ }^{13}$ As for dispute processing preferences, socio-legal scholars generally believed that individuals from less developed, collectivistic, or preliterate societies tend to prefer non-confrontational methods that reinforce social harmony, like mediation. ${ }^{14}$

At the other extreme, there are the modern, affluent, and industriallyadvanced societies (or in Felstiner's terminology a Technologically Complex

${ }^{7}$ Felstiner, supra note 1 , at 65.

${ }^{8}$ Id. at 72.

9 Id. at 67.

${ }^{10}$ Abel, supra note 1, at 296.

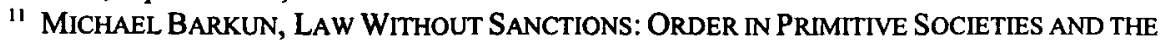
WORLD COMMUNITY (1968).

12 ROBERT H. LOWIE, PRIMITIVE SOCIETY 395 (1947).

${ }^{13}$ Felstiner, supra note 1, at 78-79; Abel, supra note 1, at 230.

14 Kwok Leung et al., Preference for Methods of Conflict Processing in Two Collectivist Cultures, 27 INT'L J. PSYCHOL. 195, 206-07 (1992). 
Rich Society-or TCRS ${ }^{15}$ ) that typically feature well-defined private and public official institutions, as well as specialized, complex, and highly technical dispute management processes. ${ }^{16}$ The formal normative system in these societies is viewed as part of a modern and sophisticated structure, which also makes it expensive to operate. ${ }^{17}$ It is, in other words, more "legal." ${ }^{18}$ In order to use this complicated apparatus, ordinary citizens have to abide by formalistic standards and to rely on lawyers or other professionals who act as brokers, go-betweens, or intermediaries. ${ }^{19}$ The scholarly work dealing with these systems is generally limited to the description of official institutions and the typical adjudicative procedures that take place within them. ${ }^{20}$

In recent years, scholars have increasingly focused on informal dispute processing methods within modern societies, ${ }^{21}$ thus slightly moving away from the traditional approach of legal centralism. ${ }^{22}$ However, these situations are described as if they only pertain to small, closed communities and are generally portrayed as an exception or rare event within a society that has learned to use arguably better and more modern and sophisticated forms of handling disputes through its official institutions. In this sense, examples of informality within modern and complex societies are seen as mere "pockets" of indigenousness and not as alternatives that modern citizens consciously choose. $^{23}$

However, not every society can be easily identified as either purely modern and industrialized or entirely traditional. Though these categories are helpful constructs, reality does not necessarily (and almost never does) fit into these

15 Felstiner, supra note 1 , at 65.

${ }^{16}$ Id.

17 Lawrence M. Friedman \& Robert V. Percival, A Tale of Two Courts: Litigation in Alameda and San Benito Counties, 10 LAW \& SOC'Y REV. 267, 269 (1976).

${ }^{18} \mathrm{Id}$. at 270.

19 Id. at 269.

${ }^{20}$ Marc Galanter, Justice in Many Rooms: Courts, Private Ordering, and Indigenous Law, 19 J. LEGAL PLURALISM \& UNOFFICIAL L. 1, 20-21 (1981).

${ }^{21}$ See, e.g., Stewart Macaulay, Non-Contractual Relations in Business: A Preliminary Study, 28 AM. SOC. ReV. 55, 56 (1963); JEROLd S. AUERBACH, Justice WithOUT LAW? (1983); ROBERT C. ELLJCKSON, ORDER WITHOUT LAW: HOW NEIGHBORS SETTLE DISPUTES (1991); John McMillan \& Christopher Woodruff, Dispute Prevention Without Courts in Vietnam, 15 J.L. ECON. \& ORG. 637 (1999).

22 See Sally Engle Merry, Legal Pluralism, 22 LAw \& SoC'Y REV. 869, 874 (1988).

${ }^{23}$ Richard Danzing \& Michael J. Lowy, Everyday Disputes and Mediation in the United States: A Reply to Professor Felstiner, 9 LAW \& SOC'Y REV. 675, 677 (1975). 
extremes. Along the spectrum, there are, for example, societies that have welldefined public institutions and market-oriented economies, that could be easily labeled as technologically advanced. But at the same time, their social structure resembles that of the stereotypical traditional community, in the sense that extended families and close-knit groups are prevalent and exert important influence upon most aspects of social life. ${ }^{24}$

As my research shows, even in the societies that contain many features of modernism, indigenous aspects often play an important role. An understanding of how social institutions perform is best gained by looking beyond the "apparent" modern/traditional dichotomy that has prevailed in scholarly discourse.

\section{B. Theoretical Paradigms and Dispute Processing}

For many years, the exploration of the ways in which the processing of legal disputes occurs in society has occupied the attention of scholars from several social-science disciplines. ${ }^{25}$

Legal and social anthropologists, for instance, have focused on describing the social conditions that motivate the emergence of disputes as cultural processes, and the ways in which individuals-as social and cultural beings - choose among several available dispute processing institutions in noninstitutionalized environments. ${ }^{26}$ The majority of this research involved ethnographic studies of small communities, villages, or tribes outside the U.S., ${ }^{27}$ which are usually portrayed as traditional, poor, and very different from

${ }^{24}$ See, e.g., Ana Julia Jatar, Competition Policy in Venezuela: The Promotion of Social Change, in COMPETITION POLICY, DEREGULATION, AND MODERNIZATION IN LATINAMERICA 95 , 111 (Moisés Naím \& Joseph L. Tulchin eds., 1999). See also LAS EMPRESAS VENEzOLANAS: Su GERENCIA 10 (Moisés Naím ed., 1989).

${ }^{25}$ See Laura Nader, The Anthropological Study of Law, 67 AM. ANTHROPOLOGIST 3 (1965).

${ }^{26}$ However, as Nader has explained, the interests of the early ethnographers of law "were strongly set in an empirical mode based on the publications of Malinowski, Llewellyn and Hoebel, Gluckman, Bohannan, Pospisil, Moore, Schapera, and Gulliver." See LAURA NADER, HARMONY IDEOLOGY: JUSTICE AND CONTROL IN A ZAPOTEC MOUNTAIN VILLAGE, at Xvi (1991) (citation omitted).

${ }^{27}$ See P.H. GULLIVER, SOCLAL CONTROL IN AN AFRICAN SOCIETY 173-302 (1963)(describing dispute procedures among the Arusha of Northern Tanganyika, currently Tanzania); Bernard S. Cohn, Anthropological Notes on Disputes and Law in India, 67 AM. ANTHROPOLOGIST 82-122 (1965) (reviewing results of research by anthropologists on questions of disputes and law in India); MAX GLUCKMAN, CUSTOM AND CONFLICT IN AFRICA (1955); J. Van Nelsen, Procedural 
the modern and affluent western societies. Through these studies, scholars focused on describing the social conditions under which several forms of dispute processing were likely to occur, ${ }^{28}$ and gave special attention to the social organization, the normative system, the available dispute processing institutions, as well as the different enforcement mechanisms present in each of these environments. ${ }^{29}$

Regardless of their differences, these societies, generally, were characterized by having a similar social structure often dominated by families, clans and other close-knit groups whose members were interconnected through multiplex, long-standing social relationships. ${ }^{30}$ Even though in the villages' countries formal public institutions were present, the social organization of the social environments subject to study still depended on the operation of informal networks, and political authority was entangled with social leadership. ${ }^{31}$ The normative system of these traditional societies was largely defined by indigenous norms that often resulted from long traditions and customary practices as opposed to the highly technical and formal legal framework of modern societies. ${ }^{32}$

Dispute processing institutions that operate in these social contexts were often cataloged as resulting from factors such as: the influence of strong social networks, an expanded family structure, and the absence of a well-defined state apparatus. $^{33}$ In addition, the fact that most members of these societies had strong social ties among themselves led researchers to believe that these environments favored a preference for conciliatory processes over adjudicatory ones. ${ }^{34}$ As for the enforcement of rights in these small societies, disputants not

Informality, Reconciliation, and False Comparison, in IDEAS AND PROCEDURES IN AFRICAN CUSTOMARY LAW 137-52 (Max Gluckman ed., 1969); Y.P. Ghai, Customary Contracts and Transactions in Kenya, in IDEAS AND PROCEDURES IN AFRICAN CUSTOMARY LAW 332-46 (Max Gluckman ed., 1969); THE DisPUTING PROCESS: LAW IN TEN SOCIETIES (Laura Nader \& Harty F. Todd, Jr. eds., 1978).

${ }^{28}$ Felstiner, supra note 1, at 62, 63.

29 Sally Engle Merry, Disputing Without Culture, 100 HARV. L. REv. 2057, 2060 (1987)

(reviewing STEPHEN B. GOLDBERG ET AL., DISPUTE RESOLUTION (1985)).

${ }^{30}$ See supra note 27.

${ }^{31}$ Id.

${ }^{32}$ See Galanter, supra note 20, at 20.

${ }^{33}$ See Austin Sarat \& Joel B. Grossman, Courts and Conflict Resolution: Problems in the Mobilization of Adjudication, 69 AM. POL. SCI. REV. 1200, 1203 (1975).

${ }^{34}$ See Dan Henderson, Law and Political Modernization in Japan, in POLITICAL DEVELOPMENT IN MODERN JAPAN 449 (Robert Ward ed., 1968); Kwok Leung, Some 
only rely on the existence of a superior authority, but on a different system in which the notions of reputation and face have great value. ${ }^{35}$ "Informal" processes, though often highly ritualistic and formalistic, were widely used in these settings. ${ }^{36}$

By offering a thick description of real-life situations, the work of legal anthropologists shed light on how the legal system works. In addition, these studies not only brought awareness to American scholars about other societies but also helped scholars understand how social control operated within these various contexts ${ }^{37}$ and in particular, the ways in which legal disputes were processed under different conditions. This line of research, however, also reinforced the notion of the apparent dichotomial view prevailing among sociolegal scholars that labeled societies as either simple, poor and primitive, or complex, rich, and modern. ${ }^{38}$

Social psychologists, on the other hand, have not paid much attention to the external forces, but rather, to individual behavior. ${ }^{39}$ Their focus has been to explore the ways in which people, as rational beings, conduct themselves and how they react to social processes (the processing of disputes being one of them) that affect their individual sphere. ${ }^{40}$ Thibaut and Walker are usually regarded among the precursors of the field of "procedural justice,"

Determinants of Reactions to Procedural Models for Conflict Resolution: A Cross-National Study, 53 J. PERSONALITY \& SOC. PSYCHOL. 898 (1987) (mentioning the work of Henderson, Kawashima, Peterson, Shimada and Doo among others, who have concluded that members of Asian societies prefer non-adjudicatory processes).

${ }^{35}$ Sarat \& Grossman, supra note 33.

${ }^{36} I d$.

${ }^{37}$ See LAW IN CULTURE AND SOCIETY, at viii (Laura Nader ed., 1969). This was, according to Nader, the focus of the Burg Warternstein conference held in Austria in 1966. Id.

${ }^{38}$ Felstiner, supra note 1, at 63.

39 See, e.g., John Thibaut et al., Adversary Presentation and Bias in Legal Decisionmaking, 86 HARV. L. REV. 386 (1972); Robin I. Lissak \& Blair H. Sheppard, Beyond Fairness: The Criterion Problem in Research on Dispute Intervention, 13 J.APPLIED SOC.PSYCHOL. 45 (1983); Larry B. Heuer \& Steven Penrod, Procedural Preference as a Function of Conflict Intensity, 51 J. PERSONALITY \& SOC. PSYCHOL. 700 (1986); Blair H. Sheppard et al., Procedural Justice from the Third Party Perspective, 54 J. PERSONALITY \& SOC. PSYCHOL. 629 (1988).

${ }^{40}$ Thibaut et al., supra note 39; Lissak \& Sheppard, supra note 39; Heuer \& Penrod, supra note 39; Sheppard et al., supra note 39.

${ }^{41}$ Donna Shestowsky, Procedural Preferences in Alternative Dispute Resolution: A Closer, Modern Look at an Old Idea, 10 PSYCHOL. PUB. POL'Y \& L. 211,216 (2004); Deborah R. Hensler, Suppose It's Not True: Challenging Mediation Ideology, 2002 J. DiSP. RES. 81, 85 (2002); E. ALLAN LIND \& TOM R. TYLER, THE SOCIAL PSYCHOLOGY OF PROCEDURAL JuSTICE 7 (1988); Kwok Leung \& E. Allan Lind, Procedural Justice and Culture: Effects of Culture, 
also credited with establishing the use of psychological laboratory experimentation for conducting legal research. ${ }^{42}$ This approach, Thibaut and Walker believed, could help scholars gain insight into the behavior of legal actors, ${ }^{43}$ and also "facilitate comparison of whole systems of conflict resolution as well as the assessment of proposed changes within individual systems." $" 44$

Social psychologists acknowledged that procedural principles are important to the study of both informal and formal processes, ${ }^{45}$ but most of their research focused on assessing institutionalized methods for dispute processing. ${ }^{46}$ After all, the prevailing interest among those interested in dispute resolution has been dominated by research focusing on legalistic, state-centered, and formal processes that take place within official institutions. ${ }^{47}$

Legal scholars have, instead, turned most of their attention to the study of formal institutions, to the official system of social control, and to the ways in which its enforcement mechanisms work. ${ }^{48}$ They have also focused on legal actors and the processes in which they participate, but this focus is frequently made from a legal centralistic viewpoint that considers government as the main source of rules and social order. ${ }^{49}$

The way in which people process their disputes matters to legal scholars, but this is generally viewed as only a component of a large, technical, and complicated structure. ${ }^{50}$ The interest of traditional legal scholars is not so much in explaining how individuals choose to actually process their disputes, but rather, how they should process them in light of the normative order that is in place.

In this sense, dispute processing mechanisms are examined in terms of formal steps and pre-existing sets of rules, while individual behavior is

Gender, and Investigator Status on Procedural Preferences, 50 J. Personality \& Soc. PSYCHOL. 1134 (1986).

42 Hensler, supra note 41 , at 85 .

43 Thibaut et al., supra note 39 , at 387.

44 John Thibaut \& LaUREns Walker, Procedural Justice: A PSychological ANalysis 1 (1975).

45 Thibaut et al., supra note 39.

46 THIBAUT \& WALKER, supra note 44.

${ }^{47}$ Galanter, supra note 20, at 20-21. But see Barak D. Richman, Firms, Courts, and Reputation Mechanisms: Towards a Positive Theory of Private Ordering, 104 COLUM. L. REV. 2328, 2330 (2004).

${ }^{48}$ Galanter, supra note 20 , at 20-21.

49 Id.

${ }^{50}$ Friedman \& Percival, supra note 17, at 269. 
observed in terms of how it conforms (or not) with what the law says. ${ }^{51}$ It is true, though, that for several years now, a number of legal scholars have expanded their interest to understand dispute processing that occurs outside formal institutions. ${ }^{52}$ However, the traditional legal centralistic approach has been so powerful and overwhelming that any attempt to offer an alternative approach looks almost insignificant.

Formal law and legal institutions have been portrayed by legal scholars as the backbone of society, as an essential component that not only guarantees social order but also progress and economic efficiency. ${ }^{53}$ As a result, since the mid-1980s, the World Bank and other multilateral institutions have led the way in advancing ambitious reform agendas that are focused on the modernization of public institutions and the promotion of the rule of law. ${ }^{54}$

In fact, most judicial reform agendas (as proposed by multilateral organizations) prescribe that in order to achieve progress, developing countries need to replicate legal institutions and processes that are used in developed and more advanced societies. ${ }^{55}$ As a result, institutions and dispute processing models have been transplanted from one place to another not only as development tools but with a wide, and sometimes contradicting, range of objectives in mind. ${ }^{56}$

The actual benefits of these initiatives have been much less than its proponents expected. This is in great part because their implementation has

51 John Griffiths, What is Legal Pluralism?, 24 J. Legal Pluralism 1, 3 (1986).

52 See David Engel, The Oven Bird's Song: Insiders, Outsiders, and Personal Injuries in an American Community, 18 LAW \& SOC'Y REV. 551 (1984); see also ELLICKSON, supra note 21, at 40; Lisa Bernstein, Opting Out of the Legal System: Extralegal Contractual Relations in the Diamond Industry, 21 J. LEGAL STUD. 115 (1992); Richman, supra note 47.

${ }^{53}$ See, e.g., Ronald H. Coase, The Problem of Social Cost, 3 J.L. \& EcoN. 1 (1960); RICHARD A. POSNER, ECONOMIC ANALYSIS OF LAW (7th ed. 2007); DAVID D. FRIEDMAN, LAW'S ORDER: AN ECONOMIC ACCOUNT (2000).

${ }^{54}$ See JUdiCLAL REFORM IN LATIN AMERICA AND THE CARIBBEAN: PROCEEDINGS OF A WORLD BANK CONFERENCE (Malcolm Rowat et al. eds., 1995); Richard E. Messick, Judicial Reform and Economic Development: A Survey of the Issues, 14 WORLD BANK RES. OBSERVER 117 (1999).

"53 IBRAHIM F. SHIHATA, THE WORLD BANK IN A CHANGING WORLD 169 (1995); IBRAHIM F. SHIHATA, COMPLEMENTARY REFORM: ESSAYS ON LEGAL, JUDICIAL AND OTHER INSTITUTIONAL REFORMS SUPPORTED BY THE WORLD BANK (1997).

${ }^{56}$ See Manuel A. Gómez, Shooting First, and Finding out Later: ADR in the World Bank Judicial Reform Agendas 15 (Jan. 24, 2003) (unpublished manuscript, on file with author). 
taken place without considering the context, the social and cultural environments of the places for which they were devised. ${ }^{57}$

In general, these efforts have been driven by the idea that "modern" institutions are a contributing factor to the creation of a competitive environment for economic growth and social development; ${ }^{58}$ and that law is a "potent tool for modernization in Third World Countries. ${ }^{59}$ Also, under this approach, dispute processing is perceived in terms of "instrumental, optimizing decision strategies." ${ }^{60}$ As a result, multilateral organizations have invested billions of dollars in assistance programs to help developing countries in modernizing their institutions; and a substantial portion of these resources has been directed to reforming the courts, regulating the legal profession, and improving existing legislation-including the laws referring to dispute processing mechanisms. ${ }^{61}$

Reform agendas have stressed the necessity for developing countries to embrace vast institutional changes and to adopt mechanisms that are believed to work well in modern societies. ${ }^{62}$ Consequently, the transplant of legal institutions and models of institutionalized processes from developed nations to developing ones has become a fairly common ingredient within these programs. ${ }^{63}$ This has been the case, for example, with ADR mechanisms, the implementation of which has been included as a key ingredient in many of those formulas. ${ }^{64}$

Additionally, most reform plans are prescriptive in the sense that they stress how public institutions ought to be and what successful experiences should be

${ }^{57}$ Id.

58 Malcolm Rowat, Competition Policy in Latin America: Legal and Institutional Issues, in GOOD GOVERNMENT AND LAW 165, 188 (J. Faundez ed., 1997).

s9 Merry, supra note 22 , at 869,879 .

${ }^{60}$ Sally Engle Merry \& Susan S. Silbey, What Do Plaintiffs Want? Reexamining the Concept of Dispute, 9 JUST. SYS. J. 151, 157 (1984).

${ }^{61}$ Shahid Javed Burki, World Bank, Judicial Reform in Latin America and the Caribbean 11-12 (World Bank, Technical Paper No. 280, 1995); Gómez, supra note 56, at 8.

${ }^{62}$ ERIK G. Jensen \& Thomas C. Heller, Beyond COMMON KNOWLEdGe: EMPIRICAL approaches to the Rule of Law (2005); Thomas Carothers, Promoting the Rule of LaW ABROAD: IN SEARCH OF KNOWLEDGE (2006).

${ }^{63}$ Burki, supra note 61, at 11-12.

${ }^{64}$ Enrique Iglesias, President, Inter-Am. Dev. Bank, Keynote Address at the Conference: Commercial Alternative Dispute Resolution (ADR) in the XXI Century: The Road Ahead for Latin America and the Caribbean (Oct. 26, 2000). 
imitated. ${ }^{65}$ On the other hand, many have not valued the importance of local ideologies or the context in which domestic institutions operate. ${ }^{66}$ According to reform advocates, the reason why developing countries are far behind in the success curve and are unattractive to foreign investors is because of the lack of well-functioning, modern institutions. ${ }^{67}$

Developing countries are also believed to be plagued with corruption and social inequality, which, according to this view, leads to inefficiency and hinders democracy. ${ }^{68}$ In sum, the paradigm that has shaped reform agendas and the scholarly work related to it is based on the assumption that rich and modern countries have better, or at least better working, institutions, which poor countries need to adopt in order to attract foreign investment and to achieve overall economic and social progress.

Even though this quest for institutionalization and modernization may have important advantages, the persistent focus on official bodies and the processes that take place within them has overshadowed other important layers of society (e.g., the informal sector) that may be perceived to work reasonably well by locals. ${ }^{69}$ This "institutional reform" approach has also contributed to the reaffirmation of the modern/traditional dichotomy that, as stressed before, has pervaded the scholarly literature.

\section{The Social Networks' Paradigm}

As social psychologists, legal anthropologists, and institutional scholars were developing and testing theories of disputing behavior and the ways to process conflict, a group of scholars from different disciplines were developing the analysis of social networks. ${ }^{70}$ Social networks have significant

${ }^{65}$ Burki, supra note 61 , at 11-12.

${ }^{66}$ See Merry \& Silbey, supra note 60 , at 159 . It is worth mentioning that this structuralfunctional approach has existed for a long time. In fact, its presence even predates the legal anthropology paradigm that emerged during the 1950s, precisely as a critical response to the structural-functional paradigm. See id. (explaining that "[e]arly proponents of the case study approach in anthropology, such as Llewellyn and Hoebel, Gluckman, Tuner, Gulliver, and Nader, were rebelling against a static, ahistorical (synchronic), structural-functional paradigm" (citations omitted)).

${ }^{67}$ Id.

${ }^{68} I d$.

${ }^{69}$ Id. at 160 .

70 See JACOB LeVy MORENo, The SOCIOMETRY REAder (1960); Noel M. Tichy et al., Social Network Analysis for Organizations, 4 ACAD. MGMT. REV. 507 (1979); Reed E. Nelson, The 
implications for the study of procedural choices, which have, to date, been largely ignored by researchers interested in dispute processing, and more specifically by studies of preferences for ADR.

The term "social network"7l denotes a set or group of individuals who are related or connected to each other by a social relationship based on friendship, cognatic kin, ${ }^{72}$ professional or work collegiality, economic linkage, religious affiliation, or some other form of affinity. ${ }^{73}$ In social network theory, the relationship between two given individuals ("nodes" ") is labeled as a "tie," and its strength depends on the combination of at least four factors: "the amount of time, the emotional intensity, the intimacy (mutual confiding), and the reciprocal services which characterize the tie." 75

One individual is usually connected to many others, who are in turn also tied to different people by relationships of varied intensity. ${ }^{76}$ When people are connected by multistrand, multichannel or "multiplex" relationships, ${ }^{77}$ strong ties are present, and, the stronger the tie, the more cohesive the network. ${ }^{78}$ Conversely, weak ties result from relationships that are less intense or generally single-stranded. ${ }^{79}$ It may also occur that two people related to a third know one another, in which case we talk about a close-knit or "high-density"

Strength of Strong Ties: Social Networks and Intergroup Conflict in Organizations, 32 ACAD. MGMT. J. 377-401 (1989); Candance Jones et al., A General Theory of Network Governance: Exchange Conditions and Social Mechanisms, 22 ACAD. MGMT. J. $911-45$ (1997).

${ }^{71}$ See J.A. Barnes, Class and Committees in a Norwegian Island Parish, 7 HUM. REL. 39 (1954).

72 ERNEST L. SCHUSKY, MANUAL FOR KINSHIP ANALYSIS 74 (1965) ("Cognatic kin are relatives by genealogical ties without particular emphasis on either patrilineal or matrilineal connections.").

${ }^{73}$ SAMUEL BOWLES \& HERBERT GiNTIS, OPTIMAL PAROCHIALISM: THE DYNAMICS OF TRUST AND EXCLUSION IN NETWORKS 2 (2000).

${ }^{74}$ See J. Clyde Mitchell, The Concept and Use of Social Networks, in SOCIAL NETWORKS IN URBan Situations 2-3 (J. Clyde Mitchell ed., 1969).

${ }^{75}$ Mark S. Granovetter, The Strength of Weak Ties, 78 AM. J. Soc. 1360, 1361 (1973).

${ }^{76}$ Mitchell, supra note 74, at 27.

${ }^{77}$ See id. at 22 . Multiplex relationships are contrasted with uniplex or single-stranded ones, "which contain only one focus of interaction." Id.

${ }^{78}$ Andreas Flache \& Michael W. Macy, The Weakness of Strong Ties: Collective Action Failure in a Highly Cohesive Group, in EVOLUTION OF SOCLAL NETWORKS 19, 20 (Patrick Doreian \& Frans N. Stokman eds., 1997).

79 The value of weak ties has been highlighted by Granovetter, who argued that low-intensity social connections are indispensable for mobility opportunity and to facilitate the linkage between members of different small groups. Granovetter, supra note 75, at 1373. 
network, ${ }^{80}$ as opposed to one in which one's friends are not related among themselves ("loose-knit network"). ${ }^{81}$

The fact that an individual, throughout his or her life, interacts with people from different social groups implies that he or she may also belong to different networks. ${ }^{82}$ As a result, that same individual will also serve as a "broker" by bridging together the networks to which he or she belongs. ${ }^{83}$ As the same phenomenon may occur with all members of society, the different chains ("partial networks"84) that exist in a given social context can be visualized as the building blocks of the larger social structure called a "total network." 85

Social networks are present in every society regardless of its level of modernity, economic affluence, political structure, or prevailing cultural norms. ${ }^{86}$ Nonetheless, the degree of cohesiveness among network participants-the network's salience, and the ways in which these structures interact with official institutions - differs from one society to another and is conditioned not only by the existing cultural and social norms, but also by the presence of institutional and legal constraints that are present in the social settings in which those networks operate. ${ }^{87}$

As a result, there are societies or, clusters within societies, in which interpersonal networking is deemed so important that most aspects of ordinary life depend exclusively on the norms that emerge from the group or clan. ${ }^{88}$

${ }^{80}$ Mitchell, supra note 74, at 18.

${ }^{81}$ Granovetter, supra note 75, at 1370.

${ }^{82}$ See R.A. Hill \& R.I.M. Dunbar, Social Network Size in Humans, 14 HUM. NAT. 53, 69 (2003).

${ }^{83}$ Conversely, several individuals may belong to the same social network and not necessarily be a part of or live in the same community. The network may be limited to a certain aspect of their life.

${ }^{84}$ See J.A. Barnes, Networks and Political Process, in SoCIAL NETWORKS IN URBAN SITUATIONS 51, 57 (J. Clyde Mitchell ed., 1969).

${ }^{85}$ Id: see also FranK HARARY ET AL., STRUCTURAL MODELS: AN INTRODUCTION TO THE THEORY OF DIRECTED GRAPHS 362-88 (1965).

${ }^{86}$ FranCIS FuKUYAMA, TRUST: THE SOCLAL VIRTUES AND THE CREATION OF PROSPERITY 41 (1995).

${ }^{87}$ As an example, in the United States, the law severely limits the existence of interlocking directories in private companies. This was essentially a result of the antitrust legislation passed between 1890 and 1934 in order to dissolve the influential capital networks that emerged within the industrial sector and monopolized the American financial markets. See PAUL WINDOLF, CORPORATE NETWORKS IN EUROPE AND THE UNITED STATES 4, 5 (2002).

${ }^{88}$ Larissa Adler Lomnitz, Informal Exchange Networks in Formal Systems: A Theoretical Model, 90 AM. ANTHROPOLOGIST 42 (1988). 
Many of these social networks have also taken part in the organization of social structures that help monitor compliance and enforcement of rights; hence these become a substitute for the official legal order. ${ }^{89}$

The salience of social networks in these environments results from the fact that its members are usually linked through multiplex relationships (e.g., by having kinsmen in common, sharing the same cultural traits, living in the same neighborhood, having attended the same schools, and sharing intergenerational friendships) and that the social distance between them is usually less than the social distance between those who live in larger and more complex environments. ${ }^{90}$

Also, due to the relatively minimal social and geographical mobility that characterizes small societies and the fact that most small societies have citizens who share common cultural values, the ties among the citizens of these societies tend to be durable and longstanding and to give rise to a higher level of social cohesion. ${ }^{91}$ In the presence of such strong social networks, insiders (i.e., members of the network) distance themselves from outsiders (i.e., nonmembers or strangers) by limiting their loyalty only to friends, relatives, and colleagues, and conversely, by excluding and avoiding transactions with those who are not part of their clique. ${ }^{92}$

Scholars call this kind of exclusionary behavior "parochialism." Parochialism may be seen as economically inefficient to the extent that it hinders interaction between network insiders and potential outside partners. ${ }^{93}$

${ }^{89}$ Id. The emergence of these private ordering structures is often portrayed as a direct consequence of the failure of official institutions in performing their role. See John McMillan \& Christopher Woodruff, Private Order Under Dysfunctional Public Order, 98 MICH. L. REV. 2421 (2000). However, there are circumstances in which social groups have devised their own private ordering regardless of how official institutions operate. See Richman, supra note 47 , at $2328-67$.

${ }^{90}$ Granovetter, supra note 75 , at 1361 n.3. The idea of social distance is directly related to the concept of reachability that is used to describe the fact that "every specified person can be contacted within a stated number of steps from any given starting point." Mitchell, supra note 74 , at 15 . This also has a direct consequence on the level of network cohesiveness. See id.

91 See James Moody \& Douglas R. White, Structural Cohesion and Embeddedness: A Hierarchical Concept of Social Groups, 68 AM. SoC. REV. 103, 105 (2003) (analyzing the notion of social cohesion, structural cohesion, and embeddedness).

92 Samuel Bowles \& Herbert Gintis, Optimal Parochialism: The Dynamics of Trust and Exclusion in Networks 2 (Santa Fe Inst., Working Paper No. 00-03-017, 2000), available at http://www.santafe.edu/research/publications/workingpapers/00-03-017.pdf.

${ }^{93}$ Id. at 2-3. 
On the other hand, parochial practices may also generate efficiency for network participants who, as a result, have access to low cost information about their trading partners and are also allowed to effectively enforce incomplete contracts through different forms of social coercion, which are only possible in small group settings. ${ }^{94}$

In contrast, there is another type of society (generally, larger ones), in which social networks are still important, but their overall influence seems to be less apparent as a result of social, cultural, economic, and legal constraints. ${ }^{95}$ Members of these large societies tend to interact with many more people than their counterparts from small ones. ${ }^{96}$ Their social circles may be larger, too, but their exchanges tend also to be briefer and more superficial. ${ }^{97}$ The complexity of life in large and generally urban environments also generates more social and geographical mobility, which in turn works towards creating less cohesive networks where the difference between insiders and outsiders is more difficult to notice. ${ }^{98}$

Since the 1930s, scholars from different disciplines (most notably, anthropology, sociology, and psychology) have systematically explored the intricacies of group dynamics and have worked towards developing an important body of literature pertaining to the study of social networks. ${ }^{99}$ Despite the diverging theoretical traits across those disciplines, social scientists interested in the field have devised a common terminology ${ }^{100}$ and a distinctive approach to explore the ways in which small-scale social interactions occur and also how these influence both individual and collective behavior. ${ }^{101}$ The social network approach usually includes diagrams, which include all relevant nodes and ties, and focuses on the attributes of interpersonal relationships by measuring the degree of relatedness among

94 Id. at 3.

${ }^{95}$ Mitchell, supra note 74, at 48.

96 Id.

97 Id.

${ }^{98}$ Franz Höllinger \& Max Haller, Kinship and Social Networks in Modern Societies: A Cross-Cultural Comparison Among Seven Nations, 6 EUR. SoC. REV. 103, 105 (1990).

99 JOHN SCOTT, SOCIAL NETWORK ANALYSIS: A HANDBOOK 7 (2d ed. 2000).

100 Id. The notion of "network" itself and several other terms used in social network analysis (i.e., intensity, frequency, nodes, ties, links) are taken from graph theory; whereas some others (e.g., multiplexity, intensity, close-knit) are from sociology or anthropology. Id. at 8-10.

${ }^{101}$ Mitchell, supra note 74, at 2. 
individuals ${ }^{102}$ rather than simply focusing on the qualities of individual actors, the social categories to which they belong, ${ }^{103}$ or more abstract social structures. $^{104}$

Social network analysis has been used to interpret interpersonal behavior in a variety of social phenomena and has contributed to understanding the usefulness of contacts for job-seeking purposes, ${ }^{105}$ the way in which organizations are run, ${ }^{106}$ how social structure affects economic life, ${ }^{107}$ the dissemination of information, rumors or ideas, ${ }^{108}$ and the mapping of corruption, ${ }^{109}$ terrorists, ${ }^{110}$ and other criminal organizations. ${ }^{111}$ Social networks have also been the subject of widespread speculation in popular culture, ${ }^{112}$ and

102 See generally THE SOCIOMETRY READER 3 (J.L. Moreno ed., 1960). Moreno coined the term "sociometry" to define the body of knowledge applied to measuring social relationships. One of Moreno's major contributions was the " 'sociogram' as a way of representing the formal properties of social configurations . . . . in diagrams analogous to those of spatial geometry." SCOTT, supra note 99, at 9-10. Modern social network scholars have traced the origins of the contemporary social networks analysis to the fundamental ideas of sociometry. See Granovetter, supra note 75 , at 1360 .

${ }^{103}$ Mitchell, supra note 74, at 10 ("[T] he categorical order by means of which the behaviour of people in unstructured situations may be interpreted in terms of social stereotypes such as class, race, ethnicity ....").

104 Id. at 4.

105 See, e.g., MARK S. GRANOVETTER, GetTING A JoB: A STUdy OF CONTACTS AND CAREERS (1974).

${ }^{106}$ See, e.g., Tichy et al., supra note 70; see also Nelson, supra note 70; Jones et al., supra note 70 .

107 See Brian Uzzi, Social Structure and Competition in Interfirm Networks: The Paradox of Embeddedness, 42 ADMIN. SCI. Q. 35 (1997).

${ }^{108}$ See James Coleman et al., The Diffusion of an Innovation among Physicians, 20 SOCIOMETRY 253 (1957); see also Max Gluckman, Gossip and Scandal, 4 CURRENT ANTHROPOLOGY 307 (1963); A. L. Epstein, Gossip, Norms and Social Networks, in SoCIAL NETWORKS IN URBAN SITUATIONS, supra note 74, at 117.

${ }^{109}$ See, e.g., John McMillan \& Pablo Zoido, How to Subvert Democracy: Montesinos in Peru, 18 J. ECON. PERSP. 69 (2004).

110 MARC Sageman, Understanding TerRor Networks (2004); Aparna Basu, Social Network Analysis of Terrorist Organizations in India (unpublished article presented at Carnegie Mellon University 2005, available at http://www.casos.cs.cmu.edu/events/conferences/2005/ 2005 _proceedings/Basu.pdf).

111 Wayne E. Baker \& Robert R. Faulkner, The Social Organization of Conspiracy: Illegal Networks in the Heavy Electrical Equipment Industry, 58 AM. SOC. REV. 837 (1993); Jeffrey Scott McIllwain, Organized Crime: A Social Network Approach, 32 CRIME, L. \& SOC. CHANGE 301 (1999); Nigel Coles, It's Not What You Know-It's Who You Know That Counts. Analysing Serious Crime Groups as Social Networks, 41 BRIT. J. CRIM. 580 (2001).

112 Perhaps the most widely known idea related to social networks is that of "six degrees of 
a notable interest on them has grown exponentially with the expansion of the Internet. ${ }^{113}$

In spite of its growing usage in other disciplines, the social network approach seems to have been overlooked by socio-legal scholars. In fact, most of the traditional literature pertaining to social control in legal environments has either focused on individual legal actors and the social categories to which they belong (categorical approach) or on the behavior of these actors depending on the role that they occupy within social institutions (structural approach). ${ }^{114}$ It could be said, for instance, that these approaches are the ones that have guided the scholarship produced under the Procedural Justice and the Structural Paradigms described earlier, and to a certain extent, have also influenced the legal anthropology paradigm as well. ${ }^{115}$

separation," according to which any two people in the world can be connected through no more than five acquaintances. This hypothesis was originally conceived by the Hungarian writer Frigyes Karinthy in a short story entitled Lánceszemek (Chains), but did not become popular until after 1967, when American psychologist Stanley Milgram conducted his "Small World Problem" experiment intended to test the six degrees hypothesis. See Stanley Milgram, PsychOL. TODAY, May 1967, at 60; see also Jeffrey Travers \& Stanley Milgram, An Experimental Study of the Small World Problem, 32 SociometRy 425 (1969). However, Milgram's findings and the Six Degrees hypothesis in general, have been recently criticized. See Judith Kleinfeld, Six Degrees of Separation: An Urban Myth?, PSYCHOL. TODAY, Mar.-Apr. 2002, available at http://www.psychologytoday.com/articles/pto-20020301-000038.html; see also Judith Kleinfeld, Could It Be a Big World After All? The "Six Degrees of Separation" Myth, SOCIETY, 2002, available at http://www.uaf.edu/northern/big_world.html.

${ }^{113}$ See Lee Sproull \& Samer Faraj, Atheism, Sex, and Databases: The Net as a Social Technology, in CULTURE OF THE INTERNET 35-38 (Sara Kiesler ed., 1997). Since the midnineties, numerous websites dedicated to promoting social networking for a variety of purposes have been launched (e.g., classmates.com, linkedin.com, sixdegrees.com, myspace.com, orkut.com, Yahoo360, and the popular facebook.com).

${ }^{114}$ Mitchell, supra note 74, at 9-10.

115 The procedural justice literature has focused on the behavior of individuals (categorical) and the choices that they make given the existing social institutions (structural); the institutional paradigm has instead focused almost exclusively on the social structure (structural) while paying no attention to the individual (categorical). See supra note 39 and accompanying text. Legal anthropologists have also, to a certain extent, focused on the structure of traditional societies and have explored the behavior of individuals according to the position that they occupy in the social system. Mitchell, supra note 74 , at 9 . However, when anthropologists began studying more complex societies, urban communities, "small scale societies which lacked single pervasive structural characteristics in terms of which their morphologies could be depicted .... [They] found the structural approach inadequate." See id. As a result, some sociologists and anthropologists began employing social network tools but most of their research was focused on the analysis of close-knit and homogeneous communities and their preference for processes that were labeled as indigenous or primitive, thus reaffirming the modem/primitive society dichotomy 
The structural and categorical approaches have provided important contributions in different contexts. ${ }^{116}$ Nonetheless, as none of these approaches focuses on social interactions and the ways in which individual behavior is affected by the social context, ${ }^{117}$ researchers have been able to obtain only a partial view of how institutions and social processes operate.

The social network approach can help obtain a more complete picture by considering context as an important element. ${ }^{118}$ To this end, social network analysis may be used as a vehicle to explore the way in which individuals cope with interpersonal conflict within social group settings, to understand the ways in which group norms are effectively enforced in the absence of a centralized formal authority ${ }^{119}$ (e.g., enforcement of incomplete contracts), and most importantly, to explain the influence of the social context on individual choices for dispute processing mechanisms and fora, in a way that goes beyond the traditional dichotomy that views societies as either traditional or modern. ${ }^{120}$ Ultimately, such analysis could also shed light on the understanding of the role of conflict in the transformation and maintenance of social structures.

The presence of social networks is a feature common to every society. ${ }^{121}$ Virtually every culture in the world considers personal exchange an essential part of life, and the building of social capital through "multiplex, affectual and

to which we have previously referred. $I d$.

116 See supra Part III.

117 It could be argued, however, that the "new legal pluralism" paradigm constitutes an exception because it not only looks at the social interactions, but also at the "unofficial forms of ordering located in social networks or institutions." Merry, supra note 22, at 869, 873.

${ }^{118}$ Robert Huckfeldt \& John Sprague, Networks in Context: The Social Flow of Political Information, 81 AM. POL. SCI. REV. 1197 (1987).

119 Even though some of its members may have more predominant roles than others, social networks usually do not have a head or a leader.

${ }^{120}$ In fact, as Mitchell points out:

$[T]$ he use of the notion of social networks in the interpretation of field data .... . $[w]$ as introduced into British social anthropology in the first instance particularly because the conventional categories of structural/functional analysis did not appear to be adequate when anthropologists began to make studies outside the ordinary run of small-scale, isolated 'tribal' societies.

See Mitchell, supra note 74, at 8. The weakness of the structural approach is that it "involve[s] generalizations about the behaviour of people in terms of the positions they occupy in the social system but that these generalizations based as they are on abstractions ignore individual deviations from the pattern." Id. at 9.

${ }^{121}$ FUKUYAMA, supra note 86. 
enduring" interactions is usually linked to the acquisition of social and economic benefits. ${ }^{122}$ Relationships that arise from business exchanges are no different. After all, deal making is a form of social interface, and the repeated interaction within groups of individuals plays an important role in fulfilling social and economic functions. ${ }^{123}$

In light of the fact that social relationships are generally perceived as paramount in business and deal making, the business community offers an ideal set of conditions for the use of social network analysis. The importance of this topic is reflected by the amount of scholarly research conducted to illustrate business social networks in Asian, ${ }^{124}$ African, ${ }^{125}$ North-American, ${ }^{126}$ and European ${ }^{127}$ cultures as well.

Many important facets of the business community can be examined through the lens of social networks, but the most relevant dimension for legal scholars is that dimension which is related to the influence of social interactions on dispute processing behavior. ${ }^{128}$ As the salient influence of social networks depends largely on the unique characteristics of every society, it is only by looking at the context in which these networks operate that we can understand their impact on the ways in which normative orderings can coexist within a

122 Abel, supra note 1, at 294.

123 WINDOLF, supra note 87, at 25 ("Corporate networks perform a number of economic functions: reducing informational asymmetries (e.g. weak ties); reducing uncertainty (e.g. trust); the supervision of managers by owners (principal-agent problem); redistributing risk (risksharing); diffusion of innovations within an 'organizational field'; reducing (mutual) resource dependency; selecting and recruiting successful managers (screening)." (citations omitted)).

124 See AsIan Business NeTworks (Gary G. Hamilton ed., 1996); CHAN KWOK-BON, MIGRATION, ETHNIC RELATIONS AND CHINESE BUSINESS (2005); Mark Granovetter, Business Groups and Social Organization, in THE HANDBOOK OF ECONOMIC SOCIOLOGY 429 (Neil J. Smelser \& Richard Swedberg eds., 2d ed. 2005).

${ }^{125}$ Marcel Fafchamps, The Enforcement of Commercial Contracts in Ghana, 24 WORLDDEV. 427 (1996); Marcel Fafchamps, Networks, Communities, and Markets in Sub-Saharan Africa: Implications for Firm Growth and Investment, 10 J. AFR. ECON. 109 (2001).

${ }^{126}$ Macaulay, supra note 21; Stewart Macaulay, Long-Term Continuing Relations: The American Experience Regulating Dealerships and Franchises, in FRANCHISING AND THE LAW: THEORETICAL AND COMPARATIVE APPROACHES IN EUROPE AND THE UNITED STATES 179 (C. Joerges ed., 1991); Eric A. Posner, The Regulation of Groups: The Influence of Legal and Nonlegal Sanctions on Collective Action, 63 U. CHI. L. REV. 133, 136 (1996); Robert E. Scott, Conflict and Cooperation in Long-Term Contracts, 75 CAL. L. REV. 2005, 2049 (1987); Emilio J. Castilla et al., Social Networks in Silicon Valley, in THE SILICON VALLEY EdGE: A HABITAT FOR INNOVATION AND ENTREPRENEURSHIP 218 (Chong-Moon Lee et al. eds., 2000).

127 WINDOLF, supra note 87.

${ }^{128}$ See Abel, supra note 1, at 225. 
given society. This is why this Article now attempts to explain the social and cultural environments under which the Venezuelan business sector operates.

\section{ALl IN THE FAMILY: Social STRUCTURE, NeTWORKS AND THE VENEZUELAN BUSINESS SECTOR}

"[C]lub reunions and birthday parties serve as a time to discuss business strategies, and board meetings serve as a time to discuss family matters. "129

\section{A. Black Gold: The Impact of an Oil-based Economy on the Venezuelan Society}

During the twentieth century, Venezuela became known as the longeststanding and most stable democracy in Latin America. ${ }^{130}$ This reputation resulted mainly because starting in 1958, and for more than forty years, the country was among the very few in the region where elections were periodically held, a formal separation of powers existed allowing the different branches of the state to be independent, citizens' rights were not only mentioned in the laws but also guaranteed to some extent, and the supremacy of the law (rule of law) was generally accepted. ${ }^{131}$ The perception of political and social stability was enhanced by the idea of economic prosperity. ${ }^{132}$ By the $1960 \mathrm{~s}$, as a result of the massive wealth coming largely from oil exports and, to a lesser extent, from other natural resources (natural gas, bauxite, and iron, among others) Venezuela became generally regarded as a rich nation. ${ }^{133}$

129 Jatar, supra note 24 , at 111.

130 Fernando CoRonIL, The Magical State: NatUre, Money and Modernity IN VENEZUELA 367-68 (1997). Almost all other Latin American countries have had long periods of dictatorship and totalitarian regimes, or to a certain extent, have only enjoyed democracy for limited periods of time. Id.

131 See id.; Howard J. Wiarda \& leda Siqueira Wiarda, Government and Politics, in VENEZUELA: A COUNTRY STUDY 133, 135, 154 (Richard A. Haggerty ed., 4th ed. 2002).

132 Terry LyNN KarL, THE PARAdOX OF Plenty: OIL BoOMS AND PETRO-STATES 71-188 (1997).

${ }^{133}$ Id. at 3. 
To this day, Venezuela is still the third largest oil producer in the world. ${ }^{134}$ As a founding and a very proactive member of Organization of the Petroleum Exporting Countries (OPEC), the international oil cartel created in 1960 that congregates mostly Middle Eastern oil rich nations, Venezuela has been a key player in the global trade of natural resources for several decades. ${ }^{135}$ Though the industry employs less than $2 \%$ of the labor workforce, oil revenues have traditionally represented more than $90 \%$ of the country's revenue from exports and at least one-fifth of Venezuela's gross national product (GNP). ${ }^{136}$

During the nineteenth century, however, Venezuela was a rural country whose economy relied on small-scale exports of coffee and cocoa. ${ }^{137}$ In fact, when the first important oil reservoirs were discovered in 1914, Venezuela did not have the technology or infrastructure to exploit and commercialize hydrocarbons, and as a result, the government had no other option but to let foreign oil corporations (FOC) handle the business. ${ }^{138}$

At the time, major oil companies, mainly from the United States and Western Europe, were among the most influential corporate actors in the world. ${ }^{139}$ The fact that these companies were completely owned and managed by foreigners contributed to the creation of a perception among Venezuelans that these entities represented a form of alien domination. ${ }^{140}$ In addition, the market presence of these financially powerful and technologically advanced actors and the contrast that they represented with respect to the local economic

134 INTERNATIONAL ENERGY AGENCY, MONTHLY OL MARKET REPORT 6 (May 12, 2006), available at $\mathrm{http}$ ://omrpublic.iea.org/tablearchivesearchres.asp?select5=2006\&Submit222 $=$ Sub mit.

${ }^{135}$ Current members of OPEC are: Algeria, Angola, Ecuador, Indonesia, Iran, Iraq, Kuwait, Libya, Nigeria, Qatar, Saudi Arabia, the United Arab Emirates, and Venezuela. See OPEC, About Us, http://www.opec.org/aboutus/ (last visited Jan. 24, 2008).

${ }^{136}$ Terry Lynn Karl, Petroleum and Political Pacts: The Transition to Democracy in Venezuela, 22 LATIN AM. RESEARCH REV. 63 (1987).

${ }^{137}$ Miguel Izard, Period de la Indepenciay La Gran Colombia: 1810-1830, PolITICA Y ECONOMIA EN VENEZUELA: 1810-1976, at 3 (Alfredo Boulton ed., 1976).

${ }^{138}$ Guillermo Rodríguez Eraso, Evolución de la Industria Petrolera en Venezuela, in SEMBRANDO El PETRÓLEO 33, 35 (2001).

139 Wayne Chatfield Taylor \& John lindeman Taylor, The Creole Petroleum CORPORATION IN VENEZUELA 1, 22 (1976); B.S. MCBETH, JUAN VICENTE GÓMEZ AND THE OII. COMPANIES IN VENEZUELA: 1908-1935, at 70 (2002). Standard Oil Co. (Creole Petroleum Co.) and Shell were the two dominant players in the Venezuelan market for more than fifty years, until the government's decision to nationalize the industry in 1975. CORONIL, supra note 130, at 108 .

140 Arturo Uslar Pietri, El UnIVERSAL (Venez.), May 27, 1991, at D6. 
players, "created the sense that the country was dominated by an uncontrollable power totally stranger to the Venezuelan society and to its possibilities, and which could defy the laws of Venezuela and even its sovereignty."141

During the 1960s, the Venezuelan government reacted to the potential foreign threat by devising protectionist strategies which it then implemented through import substitution policies, extensive price controls, fixed interest rates, and legislation that required government permits and government authorizations for almost all of business life. ${ }^{142}$ These policies were enacted not only to impede the threats of foreign competition but also to hinder local rivalry. ${ }^{143}$ For businesspeople, the only way to navigate successfully through the complicated web of administrative processes and the immense bureaucracy that emerged from the sudden growth of the state apparatus was by relying on their personal connections with government officials. ${ }^{144}$ This did not prove to be an obstacle for domestic businesspeople, given that most of them, as part of the local social elite, were already familiar with the benefit of using personal connections for their own advantage. ${ }^{145}$ Social networks may not have emerged as an effect of this economic boom, but this certainly made them stronger and more important. ${ }^{146}$

In 1975, the oil industry was nationalized, thus enabling the Venezuelan state to formally become the sole ruler of its own wealth. ${ }^{147}$ The new legislation provided that all hydrocarbons and mining reservoirs were of public interest and therefore belonged to the state. ${ }^{148}$

141 Id.

142 Jatar, supra note 24.

${ }^{143} \mathrm{Id}$.

${ }^{144}$ Id.

145 ROBERT J. FERry, THE COLONIAL ElITE of EARLy CaRACAS: Formation AND CRISIS, 1567-1767, at 217 (1989).

${ }^{146}$ Kenneth M. Roberts, Social Correlates of Party System Demise and Populist Resurgence in Venezuela, 45 LAT. AM. POL. \& Soc. 35, 39, 44 (2003).

${ }^{147}$ Mona Verma Makhija, Government Intervention in the Venezuelan Petroleum Industry: An Empirical Investigation of Political Risk, 24 J. INT'L BUS. STUD. 531, 533 (1993).

148 See Ley Organica que Reserva al Estado la Industria y el Comercio de los Hidrocarburos (LDH) [Hydrocarbons Act] (1975) (Venez.), available at http://www.villarroelsierraalta.com/ spanish/Portales/villarroelsierraalta\%5Cdata\%5C264.pdf; see also CoNSTITUCIón DE LA REPÚBLICA BOLIVARIANA DE VENEZUELA [Constitution of the Bolivarian Republic of Venezuela] art. 12 (Venez.). 
By being blessed (or cursed) ${ }^{149}$ with such a significant source of wealth from oil and other natural resources, the different administrations that ruled the country during the second half of the twentieth century found themselves in the position of playing a major role in shaping the economy. ${ }^{150}$ As a result of the financial bonanza created by the oil revenues, the state became the owner and sponsor of many economic activities and became a key player in most areas of the industrial and business sectors. ${ }^{151}$ The government was not only the richest investor but also an important benefactor. ${ }^{152}$ This in turn "imposed on the private sector the necessity for organizing and mobilizing politically so it can be first in line to benefit from rent distribution." 153 In addition, members of the business community were expected to pledge allegiance to the ruling political party as is common in relationships based on "clientelism." 154

With a need to invest and diversify its income, the state became involved in almost every important economic activity ranging from the obvious and arguably essential investments in oil, steel, and other heavy industries to areas in which liberal governments rarely participate, like airlines, hotels, telephone companies, and mass media. ${ }^{155}$ Such interventionism led to an expansion of the government's presence to include virtually every aspect of the economy and helped to strengthen the links between the public and the private sectors. ${ }^{156}$

149 See CORONIL, supra note 130, at 353-56; see also KARL, supra note 132.

${ }_{150}$ See CORONIL, supra note 130, at 353-56; see also KARL, supra note 132.

151 ALLAN BREWER-CARÍAS, RÉGIMEN JURÍDICO DE LAS EMPRESAS PÚBLICAS EN VENEZUELA (1981).

${ }^{152}$ Kevin Neuhouser, Democratic Stability in Venezuela: Elite Consensus or Class Compromise?, 57 AM. Soc. REV. 117, 117 (1992).

153 Jatar, supra note 24, at 111.

154 Jonathan Fox, The Difficult Transition from Clientelism to Citizenship: Lessons from Mexico, 46 WORLD POL. 151, 153 (1994). The term "clientelism" usually refers to "a relationship based on political subordination in exchange for material rewards." $I d$. In this manner, "politicians intervene, on behalf of voters, in the administrative process, and, in return, voters reward politicians with votes." See Lee Komito, Voters, Politicians and Clientelism: A Dublin Survey, 37 ADMIN. 171, 171 (1989).

155 BREWER-CARIAS, supra note 151.

156 Manuel A. Gómez, The Use of Institutional Mediation by Venezuelan Business Lawyers 31 (May 13, 2002) (unpublished J.S.M. thesis, Stanford University, available at http://www. law.stanford.edu/publications/dissertations_theses/diss/MAGomez-ta2002.pdf). 


\section{B. Friends Go First: The Importance of the Know-Who over the Know-How ${ }^{157}$}

As the state apparatus grew exponentially and started intervening in most areas of the economy, it became paramount to those who wanted to succeed in business to cultivate the "proper" connections. ${ }^{158}$ Obviously, certain groups achieved more power than others, and as a result, they were more successful in their business activities, often at the expense of others.

Venezuela has a racially mixed population, ${ }^{159}$ as a result of the many waves of immigration beginning in the late nineteenth century, which mainly originated from Western Europe. ${ }^{160}$ The country now has more than twentyfive million inhabitants, but the society is still visibly stratified. ${ }^{161}$ The general population has grown exponentially during the last decades, but the key players in the business community are from of the same groups that have maintained an advantageous position in society by excluding "outsiders" and have dominated the social and economic scene for years. ${ }^{162}$

157 He might have an MBA from Harvard or another important university; he might be an accomplished individual but he's not clearly one of us, so when we are deciding who to hire or who to do business with, we need to give preference to those who have our same beliefs, philosophy, and who are close of our group of friends. Even if they don't have all the credentials, we can always trust them more than the strangers. After all friends go first, you know....

Interview with Venezuelan business executive, in Caracas, Venezuela (May 12, 2006). Please note, all interviews are on file with author.

158 See LAS EMPRESAS VENEZOLANAS: SU GERENCIA, supra note 24, at 10.

159 See Chris TANNER, VENEZUELAN Migration (1980).

${ }^{160}$ For a comprehensive history of the European immigration in Venezuela see NicOLAS Mille, VeINTE AÑos de Musiues: ASPECTOS Históricos, SOCIOLÓGICOS Y JURÍdicos dE LA INMIGRACIÓN EUROPEA DE VENEZUELA (1965); CHI-YI CHEN, MOVIMIENTOS MIGRATORIOS EN Venezuela (1968); Ermila Troconis de Veracoechea, El Proceso de INMIGRación EN VENEZUELA (1986); ADELA PELLEGRINO, HISTORIA GENERAL DE LA INMIGRACIÓN EN VENEZUELA Siglos XIX Y XX (1989); Mauro Bafile, La Inmigración Europea de la Postguerra, in LA INMIGRACIÓN EN VENEZUELA (Isbelia Sequera Tamayo \& Rafael Jose Crazut eds., 1992).

161 ROBERTO BRICEÑO-LEÓN, VENEZUELA: CLASES SOCIALES E INDIVIDUOS (1992); TOMÁS VASCONI, El ESTADO Y LAS CLASES DOMINANTES EN LA VENEZUELA ACTUAL (1977).

162 Frank PARKIN, MARXISM AND ClasS THEORY: A BOURGEOIS CRITIQUE 44 (1979). The notion of "exclusionary social closure" was greatly developed by Frank Parkin, who explained it as "the process by which social collectivities seek to maximize rewards by restricting access to resources and opportunities to a limited circle of eligibles. This entails the singling out of certain social or physical attributes as the justificatory basis of exclusion." Id. at 44-45. This notion is also related to the concept of parochialism in social network theory described earlier. See supra note 93 and accompanying text. 
Some areas within the business sector still appear to be controlled by groups of a common ethnic background, but the larger community is able to form into a relatively cohesive group of people who are bound by multiplex social relationships where families are members of the same social clubs, children attend the same private schools and they travel to the same places for vacation. ${ }^{163}$ Social networks have influence over most aspects of business life, and the processing of disputes is not an exception. ${ }^{164}$

Whenever legal conflicts arise, the first move on each side is usually to resort to the network. ${ }^{165}$ Since business relationships are so intertwined with personal ties and the degree of social cohesiveness is high, it is common for disputants to sort out their differences with the intervention of other members of their social group, which may also be part of their family. ${ }^{166}$ When conflicts get out of hand, and the contending parties are not members of the same social group, or the intervention of official institutions is deemed necessary for any other reason, disputants utilize the official fora, but still through their social networks. ${ }^{167}$ In this sense, lawyers have become important players within the business sector because they are the ones who usually interact with official institutions and serve as liaisons or brokers between different social groups. ${ }^{168}$

Family-owned businesses are still very common in the Venezuelan private sector. ${ }^{169}$ Most large and medium-sized companies are still owned or controlled by members of the same families, which has facilitated the strengthening of social business networks, and has helped to maintain an important level of social cohesion between groups. ${ }^{170}$ As a result of these multiplex ties, social hierarchies have extended to business relationships, and often play an important role in shaping the way in which dealings are

${ }^{163}$ See, e.g., Jatar, supra note 24 . One distinctive feature of these social circles is the high degree of cohesiveness among its members, which often extends to more than one generation, thus creating a close-knit network.

${ }^{164}$ Manuel A. Gómez, Los Abogados de Negocios en Venezuela, 125 REVISTA DE LA FACULTAD DE CIENCIAS JURídiCAS Y POLÍTICAS dE LA UNIVERSIDAD CENTRAL DE VENEZUELA, CARACAS 23, 40 (2003).

${ }^{165} \mathrm{Id}$.

$166 \mathrm{Id}$.

167 Id. at 43.

${ }^{168}$ See id. at 23-50.

169 Interestingly, this also seems to be the case of corporate ownership around the world, as families dominate most firms both in developing and advanced economies. See Granovetter, supra note 124 , at 433 .

${ }^{170} \mathrm{Id}$. 
conducted and disputes are dealt with. ${ }^{171}$ Conversely, business issues are in turn mixed with family life and social relationships. ${ }^{172}$ As Jatar has eloquently pointed out, "club reunions and birthday parties serve as a time to discuss business strategies and board meetings serve as a time to discuss family matters."173

To an outsider, the Venezuelan business sector appears to enjoy a level of modernity typically found in industrialized and affluent societies. ${ }^{174}$ But after a closer look, this modernity reveals itself to be a facade for two reasons: first, family and social relationships still have more weight than individual merits and, second, the success of most corporations and individual businesspeople depends more on their political and social connections than on their capacity to compete and innovate. ${ }^{175}$ In other words, the know-who is much more important than the know-how. ${ }^{176}$

In sum, while social networks had been important in Venezuela for many years, the particular features of the modern state and the socio-economic reality that emerged as a result of the oil boom made them even more relevant, not only for the success of business activities, but also for dealing with disputes that arose among business actors. ${ }^{177}$ As will be discussed in the following Parts, social networks have permeated private and public institutions and the individual decisions of businesspeople to use the different kinds of dispute processes heavily depends on them. ${ }^{178}$

171 Gómez, supra note 164.

${ }^{172}$ Id.

173 Jatar, supra note 24, at 111.

174 See generally LAS EMPRESAS VENEZOLANAS: Su GERENCIA, supra note 24.

175 Id.

176 Id.

177 Id.

${ }^{178}$ See infra Parts V and VI. 


\title{
V. FROM THE TRIBES TO THE JUdiCIAL REVOLUTION: THE PERSISTENT INFLUENCE OF SOCIAL NETWORKS IN THE VENEZUELAN COURTS
}

\begin{abstract}
"Mas vale tener media vara de Juez que una vara de Justicia" (It is better to have a judge's short yardstick than a long one of justice) $)^{179}$
\end{abstract}

\section{A. Demystifying Judicial Inefficiency}

One of the most common critiques of the judiciary in Latin America is that it is inefficient, and Venezuelan courts are not an exception. ${ }^{180}$ The common perception is that courts are unable to deliver a just and equitable resolution of disputes in a timely manner. ${ }^{181}$ Processes are believed to be slow, the backlog is thought to be enormous and the costs for using the justice system are believed to be prohibitive for many disputants, especially for the poor ${ }^{182}$

In general terms, efficiency implies achieving desired results by maximizing the use of available resources. ${ }^{183}$ In plain words efficiency refers to the idea of doing more by spending less and still being able to reach an optimal outcome. Efficiency is usually measured through objective parameters like cost, which refers not only to the obvious monetary dimension ${ }^{184}$ but also to other aspects as the time or duration of a process before an expected result is achieved. ${ }^{185}$

In the case of courts, for example, the issue of cost refers both to the direct monetary value to the parties, and also to how much society in general —or the government, in more concrete terms-needs to invest in order to make the

179 Venezuelan saying commonly employed by lawyers to express that it is better to have (the favor of) a judge on our side than the favor of justice.

180 Rogelio PÉREZ-PERdomo, Políticas JudiCIALES EN VENEZUELA 15 (1995).

181 Id.

182 Jose Alberto Ramirez León, Why Further Development of ADR in Latin America Makes Sense: The Venezuelan Model, 2005 J. DISP. RESOL. 399, 400, 403 (2005).

${ }^{183}$ Peter H. Rossi et AL., EVAlUation: A SYSTEMATIC APPROACH 332 (7th ed. 2004).

184 The notion of cost not only refers to "direct expenditures but also indirect and intangible costs." See Carol H. Weiss, Evaluation 244 (2d ed. 1997).

${ }^{185}$ Efficiency analysis (cost-effectiveness analysis) offers a possibility of assessing resource allocation by comparing benefits to costs in non-commensurable terms. See ROSSI ET AL., supra note 183, at 366; see also WEISS, supra note 184, at 244 (describing the uses of a cost-efficiency analysis for program evaluation). 
system work. ${ }^{186}$ The variable "time" is logically attributed to the duration of trials, that is, how long takes from the moment when a complaint is filed to the moment when the decision or final ruling is rendered.

Another evaluation parameter used to assess efficiency is "users' satisfaction," 187 that is, asking how pleased people are with the system, and how they perceive it to address their needs or aspirations.

However, at least in Venezuela, the government has traditionally viewed the activity of the courts as an extension of the state's omnipotent power and not as a public service that should be geared to respond to citizens in a manner that satisfies them and fulfills their needs. ${ }^{188}$ Hence, the real perception of users is not deemed important and this might explain why there has been little or no concern about what citizens in general think about the judiciary. ${ }^{189}$

Notwithstanding this, as judicial reform agendas emerged, it became important to pay attention, or appear to pay attention, to disputants' perceptions about the system. ${ }^{190}$ One of the best selling points used to justify the need for reform in the judiciary was the belief that citizens have a negative opinion about the court system; and to give credibility to this claim, reform advocates have usually seasoned their assertions with anecdotes of unusual and atypical cases and with data from opinion polls. ${ }^{191}$ Scholars also seem to endorse the belief that people in general avoid the courts because of their perceived inefficiency. ${ }^{192}$

186 PÉREZ-PERDOMO, supra note 180 , at 15.

187 LUIS PASARA, REFORMAS JURÍdICAS EN AMÉRICA LATINA: CUENTA Y BALANCE 29 (2004).

${ }^{188}$ Rogelio Pérez-Perdomo, Medio Siglo de Historia Judicial en Venezuela (1952-2005), 1 DERECHO Y DEMOCRACIA 6 (2006).

189 Id.

190 Eduardo Buscaglia \& Maria Dakolias, Judicial Reform in Latin American Courts: The Experience in Argentina and Equador 4 (World Bank, Technical Paper No. 350, 1996).

${ }^{191}$ Deborah R. Hensler, Senior Fellow, RAND Inst. for Civil Justice, Address at the Conference: New Approaches for Meeting the Demand of Justice: The Contribution of Judicial Reform to the Rule of Law 7 (May 10, 2001) (transcript available at http://siteresources. worldbank.org/INTLAWJUSTINST/Resources/henslerspeech.pdf) (stressing that exceptional cases (outliers), and not the common ones, are usually considered as typical and extrapolated to describe "the system as a whole, forgetting that what attracted our attention in the first place was the fact that these were exceptional cases").

192 PÉREZ-PERDOMO, supra note 180, at 16 ("“I]n spite of the lack of data and the complexity of the evaluation, as a hypothesis we could state that the satisfaction of Venezuelans with their justice system is low and that one of the signs for this is the relatively scarce use of the courts when citizens are able to avoid using it."); see also Rogelio Pérez-Perdomo, De la Justicia y Otros Demonios, in SegurIDad JuRídica y CoMPETITIVIDAD 117, 126 (M.E. Boza \& Rogelio 
But an interesting aspect here-often overlooked by reform advocates-is that efficiency has different meanings to different groups of stakeholders. ${ }^{193}$ From the institutional standpoint, for example, efficient courts are those that are deemed capable of delivering a just and expeditious resolution of disputes at a relatively low cost to both disputants and the state, and in that way, to contribute to preserving the common welfare. ${ }^{194}$ Efficiency is also deemed very important in promoting the rule of law. ${ }^{195}$

To individual disputants or certain groups of disputants, efficiency may be perceived very differently. Their understanding of an efficient court may be that of an institution that allows them to achieve a favorable resolution to their specific dispute regardless of the positive or negative impact that it might have upon the interest of society in general. ${ }^{196}$ Speedy trials may be desirable for plaintiffs but not for defendants; and low cost dispute-processing may be an aspiration of poor litigants but not of wealthy ones, who may even find it advantageous to engage in a costly trial, particularly if it represents a burden to their poorer adversary.

This gap between the views of private citizens and that of the state can be explained by the fact that the private incentive of disputants to use the legal system is different than the social incentive to use it. ${ }^{197}$ Disputants care more about their own costs than the costs of the other party or of the state. ${ }^{198}$ While the political system seeks to consolidate democracy, make the legal system transparent, responsible to social needs, and accessible to the disadvantaged, private disputants may only want to use the system to resolve a particular dispute, vindicate their rights, or simply renegotiate with the other party. ${ }^{199}$ The data obtained from interviews with current and potential business disputants in Venezuela seem to confirm this assertion.

Pérez-Perdomo eds., 1996); Moisés Naím, Viejas Costumbres y Nuevas Realidades en la Gerencia Venezolana, in LAS EMPRESAS VENEZOLANAS: SU GERENCIA, supra note 24, at 493, 511.

${ }^{193}$ Hensler, supra note 191, at 6.

194 Id.

$195 I d$.

196 Steven Shavell, The Fundamental Divergence Between the Private and the Social Motive to Use the Legal System, 26 J. LEGAL STUD. 575, 577-78 (1997).

${ }^{197}$ Id.

198 Id.

${ }^{199}$ Id. at 579. 
In principle, the majority of the business disputants interviewed for this study seemed to agree with the idea that the judiciary is corrupt and works unequally; but at the same time, they expressed a preference for using it and-to a large extent - considered it to fulfill their needs; in other words, they generally viewed the system as efficient in spite of the conventional wisdom.

\section{The Efficiency of "Malfunctioning" Courts}

At first glance, members of the Venezuelan business community seem to agree with the criticism that is often expressed in media reports. ${ }^{200}$ I started most of the interviews by asking people about their perceptions of the judiciary, and the majority of the respondents echoed similar complaints about the bad situation of the courts in general. Many people spent time commenting about the poor condition of the court buildings, the lack of modern equipment, and the frequent strikes by court employees protesting that their salaries were not paid on time.

Lawyers, naturally, emphasized the problems of access to the court facilities since they are the ones who are supposed to use them on a daily basis. ${ }^{201}$ One is left to imagine how burdensome it is for lawyers in Caracas to stand in line for a half-hour or more to get into the elevators to enter the court building; only to wait in another line at the doors of the archives to access the docket containing the documents filed in their case; and then wait again to speak with the clerk, to file a brief, or to request a copy of a court record. In principle, this entire process may take hours and, arguably, lawyers have to go through it several times a week.

${ }^{200}$ Ricardo Combellas, La Copre ante la Urgencia Judicial, El UNIVERSAL (Venez.), Nov. 15, 1996, available at http://buscador.eluniversal.com/1996/11/15/opi_art_M15CO.shtml; Rogelio Pérez-Perdomo, ¿Cuál Reforma Judicial?, El UNIVERSAL (Venez.), Dec. 3, 1996, available at http://buscador.eluniversal.com/1996/12/03/opi_art_27344.shtml; Julio Borges, No Habrá Revolución en Venezuela sin Reforma Judicial, EL UNIVERSAL (Venez.), Nov. 28, 2004, available at $\mathrm{http}: / /$ buscador.eluniversal.com/2004/11/28/pol_ava_28A511533.shtml.

${ }^{201}$ However, in the case of medium-size and large firms, it is the paralegals or the associates who usually go to the courts on a daily basis to check if there is anything new in the docket. According to Venezuelan law, the courts are supposed to give notice to the parties about important events, but it is a custom among Venezuelan lawyers to personally appear before the court and review the file at least three times a week. This is a time-consuming activity but it is the only way of keeping reliable information up to date. 
The clients, instead, usually talked about strikes or more general problems, and interestingly, most of the time their knowledge did not seem to come from first hand experience but rather, from media reports or rumors. ${ }^{202}$ Those interviewed in general commented that it would be desirable if the government spent more resources in improving the courts, but also acknowledged that the current situation does not create a real barrier that prevents them or their clients from using the system.

After hearing all these complaints regarding the system, I expected people to report that they avoided using the courts most of the time. However, when conversations with business lawyers turned to the specifics about their practice, most of them revealed a preference for choosing the commercial courts. ${ }^{203}$ At the outset, almost no one admitted to the fact that the bulk of their cases, which are not negotiated or informally-mediated, are processed through courts. Lawyers seemed inclined to say that "the court system is a mess, only with a few exceptions," 204 but it turned out that these "exceptions" turned out to be the rule. During my interviews with business lawyers, I could confirm that, in spite of the negative connotations that emerge from the conventional image of the Venezuelan judiciary, they still consider the courts as one of the possible options for their clients, and also, the lawyers generally seem to be satisfied with their experience with these fora.

Business lawyers seem to agree that the obstacles to physical access are easily circumvented. Prominent lawyers go to courts only when their presence

${ }^{202}$ Even though it is true that a number of years ago, it was very common for court employees to go on strike very often; these kinds of protests have not occurred during the last five years, but people still make comments about the "problem of judicial employees going on strike." See Interview with Venezuelan business lawyer, partner at boutique litigation firm, in Caracas, Venezuela (Oct. 22, 2004) [hereinafter Interview \#40]. See also Paralización Indefinida de Tribunales, EL UNIVERSAL (Venez.), July 27, 2001, available at http://buscador.eluniversal.co m/2001/07/27/por_art_27108CC.shtml; Eugenio Martinez, Tribunales Siguen en Huelga, EL UNIVERSAL (Venez.), Aug. 2, 2001, available at http://buscador.eluniversal.com/2001/08/02/ pol_art_02102AA.shtml.

${ }^{203}$ Naturally, I was not interested in the cases in which the parties are compelled to use the courts, either because they have been brought as defendants or because the law requires a judicial ruling in order to recognize a legal status. My interest remained in the cases in which the parties - or at least, one of them-voluntarily chose to use the courts.

${ }^{204}$ See Interview with Venezuelan Business lawyer, Managing Partner at law firm, in Caracas, Venezuela (Mar. 19, 2004); Interview with Venezuelan business lawyer, partner at law firm, in Caracas, Venezuela (June 26, 2003); Interview with Venezuelan business lawyer, solo practitioner, in Caracas, Venezuela (July 25, 2006). 
is absolutely necessary; the rest of the time, their paralegals are the ones who attend the courts on a daily basis, and they do not need to stand in line and wait long hours to check the status of their cases. Lawyers from mid-size and large firms-the ones that usually represent business parties-have close connections with court employees, some of whom are on their payroll. Depending on the degree of trust and loyalty between the lawyer and the court official, the former might not need to monitor the docket so closely, since the inside contact would usually alert him or her when any event affecting the case is about to occur. As one interviewee mentioned, "there is trust but to a certain extent, and one has always the need to keep an eye on how these people work because they might be also helping the counterpart."205 Having the right contacts is important, even contacts with the security guards at the gates of the court building are beneficial as the guards will usually let their "friends" move ahead in order to access the elevators or allow them to use the back doors to enter the building.

Obviously, the connections that really matter are not the ones that allow lawyers and their paralegals to have physical access to the court buildings. The important incentive to use the courts rests on the connections that are developed at higher levels - with the judges and their clerks. Most of the lawyers interviewed agreed that even though the judicial system is said to be widely unproductive, there are some "competent" judges who, in their view, run very efficient courts. These are the judges with whom they have developed a patron-client relationship, or who belong to an informal network that overlaps with the network that exist among business lawyers. ${ }^{206}$

Interestingly, the majority of the relationships between lawyers (private actors) and judges (public officials) are not reciprocal, ${ }^{207}$ in the sense that only one party (the public official) is expected to act upon the influence of the other one (the private actor), whose main duty is to offer compensation (generally a bribe) in exchange for a favor. ${ }^{208}$ Furthermore, most business lawyers in

${ }^{205}$ See Interview with Venezuelan business lawyer, in litigation department of international law firm, in Caracas, Venezuela (Jan. 31, 2005).

${ }^{206}$ To a certain extent, this network overlap between private and public actors resembles the "todai-yakkai-zaikai complex" described by Taira and Wada and reported by Granovetter. See Granovetter, supra note 124, at 443.

${ }^{207}$ For a description of the issue of reciprocity in social networks settings, see Mitchell, supra note 74 , at 25 .

${ }^{208}$ This is the typical situation of an "action-set network," that is, one in which "the linkages are used for the flow of goods and services rather than the flow of information." Id. at 38 . One 
Venezuela do not consider themselves as being socially equal with judges, even if they graduated from the same law school or have other interests in common. ${ }^{209}$ There is often a steep social gradient, a distance among them, but the relationship still works efficiently, as each party clearly understands their social differences and has no aspirations to join the other's social group. ${ }^{210}$

When I asked the respondents about the special qualifications that these judges might have, I quickly learned that the perception about their competence was not based on their credentials or intellectual background. Rather, it was based on how often they favorably decided cases in which those lawyers had a vested interest. I will revisit this notion when explaining the social networks that operate within the courts.

In sum, I learned that business disputants do not seem as averse to the courts as conventional perception dictates. To a certain extent, they see courts as efficient bodies and use them selectively, ${ }^{211}$ but their allegiance to social networks plays an important role in their court selection.

of the ways in which this occurs is through patronage, where "the support is bartered for some specific promise: the resources had to be husbanded and awarded to influential people who would" do something on behalf of the other party. See id.

${ }^{209}$ For a description about stratification in social networks' settings, see Barnes, supra note 71 , at 44 .

${ }^{210}$ When analyzing the social construction of corruption, Granovetter describes an interesting example portrayed by Larissa Lomnitz in a case study about comption networks in Chile where, like in Venezuela, "business was dominated by a socially-defined upper class and the government bureaucracy by a middle-class." See Mark Granovetter, The Social Construction of Corruption 5 (Oct. 2004) (unpublished article presented at the conference: The Norms, Beliefs, and Institutions of Capitalism: Celebrating Weber's Protestant Ethic and The Spirit of Capitalism, available at http://www.economyandsociety.org/events/Granovetter_paper.pdf) (discussing Larissa Lomnitz, Reciprocity of Favors in The Urban Middle Class of Chile, in STUDIES IN ECONOMIC ANTHROPOLOGY (George Dalton ed., 1971)). In trying to explain the social interaction occurring in Chile, Lomnitz's study found that "The social distance between business interests and bureaucracy facilitated graft as a form of well-understood market exchange, in which bureaucrats willingly accepted cash or material payments in return for favors to businessmen, since the social inferiority that this implied was already well understood." Id. at 2 .

${ }^{211}$ León, supra note 182 , at 412. 
B. Dispute Processing, Networks and the Courts: From the Tribes to the Judicial Revolution of the Twenty-First Century

An average business disputant in Venezuela knows that the first step before filing a lawsuit is to identify a well-connected lawyer, a friendly court, a familiar judge, and of course, be open to gratify court employees for "being diligent."212 Judges regarded as friendly to the business community are usually labeled by executives as "decent" and "competent," even if their diligence is clearly tilted in favor of one side. ${ }^{213}$

Also, business lawyers have traditionally been judged not only for "what they know" (their particular legal skills) but more importantly, for "who they know" (their social connections); as a result, legal professionals have become brokers in the real sense. ${ }^{214}$ The stereotypical image of a network within the Venezuelan legal environment is that of a group of lawyers with political power and influence, who together with some judges and other public officials, form close-knit and strong chains known as "judicial tribes" (tribus judiciales). ${ }^{215}$ These networks became popular approximately fifty years ago, portray an extreme form of judicial clientelism, and have largely influenced the way in which the courts operate in Venezuela. ${ }^{216}$

The origin of these judicial tribes can be traced back to the early 1960s, when the national government took direct action to suppress the flourishing leftists' guerrilla movements that were seen as a threat to the young

${ }^{212}$ See Interview with Venezuelan business lawyer, in Caracas, Venezuela (June 21, 2003) [hereinafter Interview \#22]; Interview with Venezuelan business lawyer, solo practitioner, in Caracas, Venezuela (July 22, 2006) [hereinafter Interview \#65]; Interview with Venezuelan business lawyer, Head of Legal Department of Financial Institution, in Caracas, Venezuela (Mar. 22, 2004).

${ }^{213}$ Granovetter has called "neutralization" the phenomenon by which an individual "acknowledges the causal connection between a payment and a service, or that items have been appropriated as the result of a position held, but implies that given the particular circumstances, no moral violation has occurred." Granovetter, supra note 210 , at 2 (emphasis in original).

214 "Brokerage" is another form of relationship that occurs in action-set networks when one individual acts as a go-between between two networks, by bridging them together. RONALD S. BURT, BROKERAGE AND CLOSURE: AN INTRODUCTION TO SOCIAL CAPITAL 10-13 (2005).

${ }^{215}$ La Tribu de Carmen, ElUNIVERSAL(Venez.), Mar. 12, 2006, available at http://buscador. eluniversal.com/2006/03/12/pol_apo_12190F.shtml; Respuestas a Acusacionesy Otros Detalles de Sus Planes, EL UnIVERSAL (Venez.), Feb. 24, 2005, available at http://buscador.eluniversal. com/2005/02/24/pol_apo_24106B.shtml.

${ }^{216}$ Respuestas a Acusaciones y Otros Detalles de Sus Planes, supra note 215. 
Venezuelan democracy. ${ }^{217}$ The government's reaction to the growing activity of these rebel groups was to prosecute them in military courts, as these fora were easily controlled by the executive. ${ }^{218}$ However, as some cases had to be tried in ordinary criminal courts, the executive decided to expand its sphere of influence and moved in order to expand its political control over those courts as well. ${ }^{219}$

Prominent political leaders who were also lawyers, and therefore familiar with the court system, were entrusted with the task of assuring governmental control over the judiciary. ${ }^{220}$ David Morales Bello, a well-known lawyer and politician, became widely recognized for his vast control over a number of judges and for leading the first clan-like group that would later be known as David's Tribe (la tribu de David). ${ }^{221}$ Another famous tribe that controlled a large portion of the courts was the Borsalino Clan, which was named for a type of hat worn by one of its key leaders. ${ }^{222}$

Even though the purpose of the government controlling the judiciary was apparently limited to assuring institutional stability and preventing the leftist movements from spreading over the country, politicians rapidly saw it as a window of opportunity to expand their influence, and the main political parties became increasingly involved in exerting influence on how judges were appointed and how the judiciary worked. ${ }^{223}$ Before many people even realized it, the leading political parties literally divided the country into areas of influence, each retaining control over a certain number of jurisdictions or

${ }^{217}$ Pérez-Perdomo, supra note 188.

${ }^{218} \mathrm{Id}$.

${ }^{219} \mathrm{Id}$

220 Id.

221 CoRONIL, supra note 130, at 342-43; Pérez-Perdomo, supra note 188. See Rodolfo Baptista, Puchi: El CNE No Peude Ceder a Presiones de la Tribu de David, EL UNIVERSAL (Venez.), Dec. 1, 1998, available at http://buscador.eluniversal.com/1998/12/01/pol_art_0111 6GG.shtml.

${ }^{222}$ The presence of a leader shows that these "tribes" are slightly different from most social networks in the traditional sense. Networks do not usually have a head or a hierarchically superior authority; and the decisionmaking process within them occurs as a result of a consensus among the participants in the absence of a centralized entity. However, the Venezuelan judicial tribes have a clear leader who is considered the central figure and who is also regarded as hierarchically superior in relationship with the other members, and as such, is in charge of coordinating the activities of the network.

${ }^{223}$ See Pérez-Perdomo, supra note 188. 
courts. ${ }^{224}$ This became more evident, and to a certain extent "institutionalized" after 1969 when the Judicial Council was created. ${ }^{225}$ Early on, the Council became controlled by members of the political party who had the majority of seats in Congress and in the Administrative Chamber of the Supreme Court, which obviously gave it a large amount of leverage. ${ }^{226}$ For years to come, the judiciary was populated by judges chosen more because of their political allegiance than their legal competence or merits. ${ }^{227}$

The process of appointing judges was one of intense negotiations among political actors. ${ }^{228}$ It was an unwritten rule that those who wanted to enter into the judiciary needed a political sponsor (padrino), which produced a relationship of subordination between the candidate and his or her supporter in the case the first got appointed. ${ }^{229}$ Among the usual backers there were influential politicians, some of whom were connected with lawyers who in turn were key members of the judicial tribes. ${ }^{230}$ Leaders of the business community were, to a certain extent, members of these networks of power, which translated into clear benefits for them. ${ }^{231}$

The tribes were clan-like structures led by private lawyers who had been involved in politics or were fundraisers for political campaigns and therefore had connections with important political parties or the government. Some tribes were actually led by retired judges who after leaving the bench decided to go back to private practice and to keep their influence upon some courts. ${ }^{232}$ Some groups had spheres of influence in particular areas (e.g., criminal courts) or levels (e.g., trial courts, Superior Courts, or the Supreme Court itself) while others were known for having control over a certain jurisdiction. ${ }^{233}$

${ }^{224}$ Id.

225 Id.

226 Id.

227 Id.

228 Id.

229 As a result, the judicial career became a sort of social network in itself, reserved to those bound by common political affiliations, and the need for a sponsor became an entry-barrier as typically occurs in close-knit networks. See Werner Raub \& Jeroen Weesie, Reputation and Efficiency in Social Interactions: An Example of Network Effects, 96 AM. J.SocıOL. 626, 626-54 (1990).

${ }^{230}$ See Baptista, supra note 221.

${ }^{231}$ Id.

${ }^{232}$ Pérez-Perdomo, supra note 188.

${ }^{233}$ See Interview with former Venezuelan Judge, in Caracas, Venezuela (June 24, 2003) [hereinafter Interview \#25]; Interview with former Venezuelan Prosecutor, in Caracas, 
Active judges, public defenders, and prosecutors were also part of the tribes. ${ }^{234}$ Even though these groups worked informally and very cautiously, their involvement in notorious cases and subsequent scandals during the early 1990s led to wide media coverage about their existence, structure, and membership. ${ }^{235}$

The main purpose of these networks was to manipulate the courts in order to get favorable decisions for their clients, to speed the handling of judicial processes, or to simply counteract the negative influence of another clan favoring the other side. ${ }^{236}$ Each of these tribes had a law firm as a facade. ${ }^{237}$ The firm would offer its clients the guarantee of a speedy trial, with a favorable decision, and would often assure clients of positive results on possible appeals and even, if necessary, at the Supreme Court level. ${ }^{238}$ The lawyers of the firm would usually set their fees very high since they had to include the "work" of others. 239

The firm also served as a hub to all members of the network, and a small group of lawyers (brokers) centralized the communication with judges, clerks, and other public officials. ${ }^{240}$ Some active judges were permanently tied to particular tribes, while others were known to freelance by collaborating with several different groups on a case-by-case basis. ${ }^{241}$ Business lawyers were also part of these webs, and although many of them maintained a very low profile, ${ }^{242}$ their reputation as effective professionals largely depended on how close they were to the heart of the network. ${ }^{243}$ Lawyers not only used the networks to process cases in courts, but also to get help bypassing regulatory

Venezuela (Oct. 27, 2004) [hereinafter Interview \#44].

${ }^{234}$ See Pérez-Perdomo, supra note 188; Baptista, supra note 221.

${ }^{235}$ Pérez-Perdomo, supra note 188.

236 See Interview \#25, supra note 233; Interview \#44, supra note 233.

${ }^{237}$ See Interview \#25, supra note 233; Interview \#44, supra note 233.

${ }^{238}$ See Interview \#25, supra note 233; Interview \#44, supra note 233.

239 See Interview \#25, supra note 233; Interview \#44, supra note 233.

${ }^{240}$ See Interview \#25, supra note 233; Interview \#44, supra note 233.

${ }^{241}$ See Interview \#25, supra note 233; Interview \#44, supra note 233.

242 See Interview \#25, supra note 233; Interview \#44, supra note 233. Socially, it was seen as undesirable for upper-class lawyers and business executives to be seen interacting with lowclass court officials, so the former tended to act in a covert manner or through intermediaries.

${ }^{243}$ See Interview \#25, supra note 233; Interview \#44, supra note 233 . In other terms, depending on their social distance to the ego (individual regarded as the center of the network). 
processes, dealing with government authorities, and negotiating disputes outside the formal system. . $^{244}$

The mid-1990s witnessed a crisis among the traditional political parties who lost legitimacy and therefore their traditional power and influence within the political arena. ${ }^{245}$ After the two failed coups d'etat of 1992, the Venezuelan political elite became increasingly fragile, which also affected their spheres of influence on the judiciary. ${ }^{246}$ About the same time, high profile corruption cases involving judicial networks were denounced by the media, ${ }^{247}$ which made the judicial tribes weaker and eventually led to their demise. ${ }^{248}$ The pacts according to which the leading political parties had shared their control over the courts slowly eroded; remaining members were left on their own. ${ }^{249}$ A number of retired judges who had amassed some power during the previous years became leaders of their own small-scale corruption rings, thus becoming judicial entrepreneurs of a sort. ${ }^{250}$ These judges were only capable of cutting deals involving cases being tried in their own former courts or in others in which they still had connections. ${ }^{251}$. The network based system became less efficient due to the fact that participants were only tied by one dimensional, single stranded, and relatively weak relationships.

As opposed to what occurred during the climax of the judicial tribes' time, the facade of these new groups were not law firms but the individual judges themselves, or their clerks. ${ }^{252}$ The situation became more complicated for business disputants and their lawyers who were now forced to establish new connections. ${ }^{253}$ These difficulties did not last for long. ${ }^{254}$

244 See Interview \#25, supra note 233; Interview \#44, supra note 233.

${ }^{245}$ See Interview \#25, supra note 233; Interview \#44, supra note 233.

${ }^{246}$ Pérez-Perdomo, supra note 188 , at 15.

247 Id.

${ }^{248}$ Id. In spite of the tribes' notorious influence and power, most of their members were tied only through uniplex relationships, and once these relationships were affected or one of the most salient members (the leader) was disabled the entire network suffered.

${ }^{249}$ See Interview \#25, supra note 233; Interview \#44, supra note 233.

${ }^{250}$ This system resembles the Japanese example of "amakudari" (descent from heaven) described by Granovetter to depict "the movement of retired government officials to positions in industry from which they activate their social networks in the state bureaucracy to help coordinate state-business interactions." Granovetter, supra note 124, at 443.

251 See Interview \#25, supra note 233; Interview \#44, supra note 233.

252 See Interview \#25, supra note 233; Interview \#44, supra note 233.

253 See Interview \#25, supra note 233; Interview \#44, supra note 233.

${ }^{254}$ See Interview \#25, supra note 233; Interview \#44, supra note 233. 
With the advent of the "Bolivarian Revolution" that started in 1998, the existing political structures suffered an important change. ${ }^{255}$ New President Hugo Chávez, a leader of the first 1992 coup attempt, vowed to undertake a complete overhaul of the state institutions plus a deep legal reform process, including the drafting of a new Constitution. ${ }^{256}$ As part of this process, a Judicial Emergency decree was issued in 1999 with the general purpose of cleaning up the judicial system. ${ }^{257}$ This emergency legislation vested Congress with ample powers to restructure the judiciary through the power of removal and appointment of judges, the ability to make decisions on the judicial budget, to create a Commission for Judicial Reform, and in general, to control all matters related to the functioning of the court system. ${ }^{258}$

One of the first actions taken by the Emergency Commission was the dismissal or suspension of a large number of judges under charges of corruption or unjustified delay in deciding the cases brought before them. ${ }^{259}$ During the following months of the same year, 340 judges were summarily dismissed. ${ }^{260}$

From the outset, it was simple to realize that these actions were mainly motivated by political retaliation against the traditional political establishment and not by an altruistic interest to remove corrupt judges and to improve the system. ${ }^{261}$ As a clear signal of this, many of the dismissed judges were replaced by militants of President Chávez's political party, and to guarantee their unconditional loyalty to the regime, their appointment was temporary so they could be easily dismissed when necessary. ${ }^{262}$ By 2001, these appointments accounted for more than $80 \%$ of the total number of judges. ${ }^{263}$ Traditional judicial cartels did in fact disappear, but, ironically, the new structure created a breeding ground for an even more politicized judiciary in which not only a group, but all judges, are expected to pay unconditional

${ }^{255}$ See Pérez-Perdomo, supra note 188, at 23.

256 Id.

257 Id.; see also HUMAN RIGHTS WATCH WORLD REPORT 2000, at 150 (1999), available at http://www.hrw.org/wr2k/americas-09.htm.

258 See Pérez-Perdomo, supra note 188.

${ }^{259}$ Id.

${ }^{260} I d$. This number represents about a third of the total number of existing judges by that time. See id.

${ }^{261}$ See id.

${ }^{262}$ Id.

${ }^{263}$ Id. 
loyalty and to be aligned with the official party or face summary dismissal. ${ }^{264}$ This seems to be the true face of the "judicial revolution" in Venezuela. ${ }^{265}$

Almost six years after the judicial emergency was declared, Venezuela now has an overtly politicized judiciary in which new cartels and close-knit groups have emerged under the shadow of the president's political project. ${ }^{266}$ The big difference now is that only those who have connections within the ruling political party can take advantage of the influential cartels that have permeated the courts. ${ }^{267}$ The system is more loyalty-based than in the past, and business disputants are still able to find their way around. ${ }^{268}$

As discussed in the previous part, the Venezuelan private sector evolved in an environment in which the government was a prominent player. ${ }^{269}$ As a result, even the most ordinary actors learned to deal with political influence at all levels. ${ }^{270}$ Some have criticized these patterns of behavior as colliding with the ideals of democracy, free competition, equality, and economic freedom, ${ }^{271}$ and whereas this might be true, it is also certain that many people-and particularly those from the business sector-have benefited from this circumstance. ${ }^{272}$ In the recent years, the country has certainly experienced

${ }^{264}$ See Pérez-Perdomo, supra note 188 (describing the tactics used by the Venezuelan government to dismiss judges without cause).

${ }^{265}$ Very often, representatives from the government refer to the restructuring of the court system as the "judicial revolution," just to be consistent with the label that President Chávez uses for his regime, which he usually refers to as the Bolivarian Revolution (la revolución Bolivariana). RICHARD GOTT, HUGO CHAVEZ AND THE BOLIVARIAN REVOLUTION (2005); Jeffrey Cedeno, Venezuela in the Twenty-First Century: 'New Men, New Ideals, New Procedures,' 15 J. LATIN AM. CulTuRal STUD. 93 (2006).

${ }^{266}$ See Pérez-Perdomo, supra note 188.

${ }^{267}$ During the summer of 2006, a large-scale corruption scandal caught the attention of the local media in Venezuela. A group of lawyers and judges are believed to be linked to corruption scandals, for rendering favorable decisions to criminal networks and extorting citizens. This group has been labeled as la banda de los enanos (the band of the dwarfs) and is said to be formed of at least fifteen judges in Caracas and 400 nationwide, and it is believed to have adopted a similar structure to the judicial tribes of the 1970s and 1980s. See Fiscal General: "Queremos ahondar en las denuncias sobre la Banda de los Enanos, " ELUNIVERSAL(Venez.), June 29, 2006, available at http://buscador.eluniversal.com/2006/06/29/pol_ava_29A735095. shtml.

${ }^{268}$ See Pérez-Perdomo, supra note 188.

${ }^{269}$ See Jatar, supra note 24.

270 Id.

271 Id. at 98.

272 See Interview \#22, supra note 212; Interview with Venezuelan in-house counsel, in Caracas, Venezuela (Mar. 24, 2004); Interview with Venezuelan business buyer, Partner at 
many changes as a result of the "Bolivarian Revolution," and to a certain extent, this has reshaped many of the traditional structures that were in place. ${ }^{273}$ While Venezuela's population has grown in the past forty years, ${ }^{274}$ its society continues to work under the same basic social norms, particularly the heavy reliance on networks. More than ever, the "know-who" (having the right connections) makes a big difference in allowing people to be successful in many activities, including the processing of legal disputes.

It is true that the traditional networks and the so-called judicial tribes are long gone, but it is also true that new groups with a similar structure have emerged. ${ }^{275}$ Over the years in which I conducted the field research for this investigation, I found it interesting to witness how business disputants have adapted to the changes and how they have positioned themselves successfully in light of the current conditions. When I first interviewed people about these issues at the dawn of the political transition (2001 and 2002), many seemed to be worried about the political changes that were underway and expected to face numerous difficulties. It was not uncommon to hear lawyers complain about having lost their contacts in certain courts and to comment on how difficult it had become to litigate in an environment that, in their view, offered no room for predictability.

To them, uncertainty meant having to use the courts without the help of their social connections. Their ideal scenario was one in which they could still rely on their contacts to manipulate the system. This obviously seems like a contradiction, when we realize that the quest for institutional reform has been geared precisely to eradicate the predominant role of corrupt networks and to replace them with transparent and neutral institutions.

During many of the follow-up interviews that I conducted in the years from 2003 to 2006, it was interesting to observe how some of the people who were initially hopeless, had found their way around the system. "It was a matter of time," ${ }^{276}$ one prominent lawyer declared, making clear reference to the process

international firm, in Caracas, Venezuela (June 25, 2004)]; Interview with Venezuelan executive with law degree, in Caracas, Venezuela (July 20, 2006).

${ }^{273}$ See GoTT, supra note 265; Cedeno, supra note 265, at 94.

274 Jeffrey Kentor, The Long Term Effects of Globalization on Income Inequality, Population Growth, and Economic Development, 48 SOC. PROBLEMS 435, 435 (2001).

${ }^{275}$ See La Tribu de Carmen, supra note 215.

${ }^{276}$ See Interview \#22, supra note 212; Interview \#65, supra note 212; Interview with business executive and experienced lawyer, in Caracas, Venezuela (Jan. 27, 2005) [hereinafter Interview \#45]. 
of getting accustomed to working with the new networks, establishing new ties and reconnecting old ones. Whenever we asked about how the situation is different compared to the old way of dealing, I was told that:

we are the same people, governments may change and some other things will vary, but the people are still the same; so after all, things are working in a similar way to that in the past. Of course, the players are in different positions but we are all the same ... it is, if I may say, the Venezuelan way of dealing with things. ${ }^{277}$

The speaker concluded with a common Venezuelan saying that goes: "God may squeeze but never chokes (Dios aprieta pero no ahorca)."

While it is true that judicial tribes and other forms of corruption networks have existed and played a salient role in Venezuela, it cannot be said that every single dispute has to go through a network in order to be decided. Ordinary citizens can certainly use the courts without needing to use connections, "but knowing which specific key to play makes things a lot easier,"278 and certainly, in the business community that seems to be the right way to proceed.

\section{THANKS BUt No Thanks: The ModeSt ACCEPTANCE OF ADR PROVIDING ORGANIZATIONS IN VENEZUELA}

This Part illustrates how the members of the Venezuelan business sector have continued to use mediation within their social networks' environments, even after the institutionalization of ADR processes in Venezuela.

In order to justify their formulas, reform advocates have stressed that the implementation of ADR mechanisms was a necessity given the chaotic condition of the court system and the need to provide disputants with modern and efficient processes. ${ }^{279}$ As a result, enormous resources were spent on the promotion of institutionalized arbitration and mediation, but business disputants continued to address their grievances in the informal way with

${ }^{277}$ Interview \#22, supra note 212; see also Interview \#45, supra note 276; Interview \#65, supra note 212.

${ }^{278}$ Interview \#22, supra note 212; see also Interview \#45, supra note 276 ; Interview \#65, supra note 212.

${ }^{279}$ Iglesias, supra note 64. 
which they were familiar. ${ }^{280}$ This Part contains a further elaboration of a previous research project through which I explored why business lawyers stay away from the newly created arbitration and mediation centers and instead use informal processes. ${ }^{281}$

\section{A. ADR and Judicial Reform Agendas: Shooting First ...}

Court-connected ADR has been promoted in the United States mainly as a way for speeding civil case resolution and reducing litigations costs. ${ }^{282}$ Its perceived attribute as a docket-clearing device ${ }^{283}$ made ADR attractive not only to American judges, but also to multinational organizations and foreign governments, who during the mid-1980s began including judicially-sponsored ADR in their plans to revamp courts and achieve structural changes to public institutions. ${ }^{284}$ Soon, the implementation of ADR mechanisms became one of the key elements of both domestic and internationally-sponsored judicial reform agendas throughout Latin America. ${ }^{285}$

Reform advocates from elsewhere, however, did not realize that courtconnected ADR was devised in the United States for fine-tuning the judiciary and not for rethinking it. ${ }^{286}$ Also, they did not take into consideration that the success of court-connected ADR in the United States was more a desire than a proven fact. ${ }^{287}$

${ }^{280}$ See Gómez, supra note 156.

${ }^{281}$ Id.

${ }^{282}$ Hensler, supra note 191; see also Deborah R. Hensler, Our Courts, Ourselves: How the Alternative Dispute Resolution Movement is Re-Shaping Our Legal System, 108 PENN ST. L. REV. 165, 185 (2003).

${ }^{283}$ Carrie Menkel-Meadow, Do the "Haves" Come Out Ahead in Alternative Judicial Systems?: Repeat Players in ADR, 15 OHO ST. J. DISP. RES. 19 (1999).

284 HarR Y Blair \& GaRy HaNSEN, WEIGHING IN ON THE SCALES OF JUSTICE 14, 19 (1994).

285 Burki, supra note 61.

${ }^{286}$ Deborah R. Hensler, Senior Fellow, RAND Inst. for Civil Justice, Remarks at World Bank Alternate Dispute Resolution Workshop: Empirical Research on ADR Programs 44 (Jan. 6, 2000) (transcript available at http://siteresources.worldbank.org/INTLAWJUSTINST/Resourc es/TranscriptOfWorkshop.pdf).

${ }^{287}$ Hensler, supra note 282, at 178, 194, 195. 
Based on the perception that alternative mechanisms are widely used by disputants in affluent and developed societies ${ }^{288}$ —namely the United States-because of their potential for offering an efficient way to handle disputes, reform advocates at different levels have proposed them as a way to achieve a wide array of objectives. These include facilitating access to justice and helping decongest the courts, encouraging foreign investment, and thus, aiding in the achievement of economic development. ${ }^{289}$

Reform advocates in Latin America have stressed that the true demand for alternative mechanisms at the domestic level is high, but the lack of a modern legal framework has acted as a barrier, ${ }^{290}$ thus confining disputants to conform themselves with the allegedly malfunctioning courts. This had led to the belief that the implementation of modern ADR legislation, the investment of resources in training, and the sponsorship of institutional providers can contribute to meeting such needs. ${ }^{291}$

Following this idea, both the Venezuelan government and the private sector embarked on a crusade to advocate the promotion of ADR mechanisms, also believing that it would help decongest the ill-functioning courts, in addition to allowing citizens to address their legal disputes in an expeditious, inexpensive, and efficient manner. ${ }^{292}$ This, advocates believe, is the trend in modern nations where ADR mechanisms have become very popular and have also proved to be efficient tools for solving many problems related to the administration of justice. ${ }^{293}$

Strong governmental support for ADR became evident with the passage of several laws providing for the use of mediation and arbitration in different areas such as labor, consumer rights, insurance, and family law. ${ }^{294}$ As a

${ }^{288}$ This approach is what I called the "Structural Paradigm," and as explained earlier, it reaffirms the apparent dichotomy of modern/primitive societies so frequently depicted in studies about the functioning of legal institutions. See supra Part III.

289 Iglesias, supra note 64.

290 Adriana Polania, Los ADR en Latinoamérica (Oct. 26, 2000) (unpublished article presented at the conference: Commercial ADR in the XXI Century).

${ }^{291}$ León, supra note 182 , at 414-17.

${ }^{292}$ Manuel A. Gómez, Assessing ADR Providers in Latin America: Venezuela's Business Center for Conciliation and Arbitration (CEDCA) (2004) (unpublished manuscript, on file with author).

${ }^{293}$ Business Center for Conciliation and Arbitration, Rules of Conciliation and Arbitration, http://www.cedca.org.ve/cedca-ingles/rules.htm (last visited Jan. 28, 2008).

${ }^{294}$ See Gómez, supra note 156. 
corollary, the Constitution, approved in 1999, made the promotion of alternative mechanisms part of a state policy. ${ }^{295}$

In 1998, the Commercial Arbitration Act (CAA) was passed. ${ }^{296}$ Shortly thereafter, the two main chambers of commerce sponsored private arbitration centers. ${ }^{297}$ In addition, conferences and other academic events that focused on the perceived advantages of alternative mechanisms were organized, law schools began including ADR-related courses in their curricula, and several private institutions began offering workshops to inform lawyers and citizens in general about the benefits of these alternative mechanisms. ${ }^{298}$ By 2000, an extensive ADR machinery was already in place and its supporters claimed that the users of the legal system would embrace this panacea almost overnight. ${ }^{299}$

\section{B. $A D R$ and the Private Sector}

As also happened in most other countries with institutional reform plans, the Venezuelan business sector became the focus of special attention, mainly because of the idea among reform advocates that promoting ADR would help foster legal certainty and confidence in institutions. ${ }^{300}$ Judicial reform advocates believed that a stable institutional environment would attract foreign investors to the region, who otherwise, would not conduct business in countries with such weak legal systems. ${ }^{301}$ An increase in the amount of foreign investments would, in turn, help the country to achieve its desired economic development. ${ }^{302}$

${ }^{295}$ Article 258 of the Venezuelan Constitution establishes that: "The law will promote arbitration, conciliation, mediation and any other alternative dispute resolution mechanisms." CONSTITUCIÓN DE LA REPUBLICA BOLIVIARIANA DE VENEZUELA [Constitution of the Boliviarian Republic of Venezuela] art. 258 (Venez.).

${ }^{296}$ Ley de Arbitraje Comercial [Commercial Arbitration Act] (1998) (Venez.).

297 See Gómez, supra note 292, at 8.

298 Id.

${ }^{299}$ Mariela Leon, Centro de Arbitraje Comercial Inicia Sus Operaciones, El UNIVERSAL (Venez.), Mar. 12, 2006, available at http://noticias.eluniversal.com/2001/03/12/12202CC. shtml.

300 See Polania, supra note 290.

301 See Amanda Perry, Effective Legal Systems and Foreign Direct Investment: In Search of the Evidence, 49 INT'L \& COMP. L.Q. 779, 781 (2000).

${ }^{302}$ Amartya Sen, What Is the Role of Legal and Judicial Reform in the Development Process? (June 5, 2000) (unpublished article presented at the World Bank Conference on Comprehensive Legal and Judicial Development, available at http://www1.worldbank.org/publicsector/legal/ legalandjudicail.pdf); but see Beatrice Weder, Legal Systems and Economic Performance: The 
Today, a common idea ${ }^{303}$ is that ADR and, particularly, mediation are among the most preferred methods for business disputants. ${ }^{304}$ The perception is that these mechanisms not only allow the parties to gain control over both the process and the outcome, ${ }^{305}$ but are also cheaper and faster than ordinary litigation, ${ }^{306}$ even though there is no robust empirical evidence to support such assertions. ${ }^{307}$ Conversely, executives are believed to dislike litigation because of the perceived risks and uncertainty generally associated with it. ${ }^{308}$ But the notions of arbitration and mediation are by no means new to members of the business sector.

In the United States, for example, business disputants were familiar with binding arbitration long before ADR became a fashionable idea. ${ }^{309}$ Businesspeople used arbitration to process their grievances in a way that "assured that their shared customs, however idiosyncratic, would be respected." 310 Decisions were made by a third party, usually selected from among members of the community, and these decisions were often based on

Empirical Evidence, in JUDICIAL REFORM IN LATIN AMERICA AND THE CARIBBEAN 21 (Waleed Malik et al. eds., 1995); Burki, supra note 61, at 21-26 (maintaining that "there is no clear evidence of the economic costs of weak legal systems [since] research conducted on the economic costs of a badly working legal system is mostly anecdotal or in the form of individual case studies").

${ }^{303}$ Hensler, supra note 41 , at 81,83 .

${ }^{304}$ However, as Hensler points out, "[b]ecause there are no comprehensive statistics on cases that use alternative dispute resolution mechanisms in the private sector, the relative popularity of arbitration and mediation is currently unknown." Hensler, supra note 282 , at $183 \mathrm{n} .76$. Notwithstanding, some studies have reported an increasing use of ADR for business disputes. See DeloItTE \& TOUCHE, LITIGATIONS SERVICES DIVISION 1993 SURVEY OF GENERAL AND OUTSIDE COUNSELS: ALTERNATIVE DISPUTE RESOLUTION (summarizing the results of a survey among the Fortune 1,000 corporations and showing that $68 \%$ favored the use of mediation); David B. Lipsky \& Ronald L. Seeber, Patterns of ADR Use in Corporate Disputes, 54 DisP. RESOL. J. 66 (1999) (concluding that the shift from traditional litigation toward the use of ADR is one of the foremost important trends in corporate America in the 1990s). Eighty-seven percent of the surveyed population reported having used mediation and $80 \%$ reported having used arbitration at least once in the past three years. Id.

${ }^{305}$ David B. Lipsky \& Ronald L. Seeber, Top General Counsels Support ADR, 8 BUS. L. TODAY 24 (1999).

${ }^{306}$ Lipsky \& Seeber, supra note 304, at 66.

${ }^{307}$ Hensler, supra note 282 , at 178 . See also Hensler, supra note 41.

${ }^{308}$ Lipsky \& Seeber, supra note 305. But see John Lande, Failing the Faith in Litigation? A Survey of Business Lawyers' and Executives' Opinions, 3 HARV. NEGOT. L. REV. 69 (1998).

${ }^{309}$ Hensler, supra note 282, at 181.

${ }^{310}$ AUERBACH, supra note 21, at 102. 
special business norms rather than official state law. ${ }^{311}$ A similar phenomenon has occurred in other western societies. ${ }^{312}$

Almost a hundred years ago, due to sustained pressure from the American business community, arbitration became formally accepted within the legal system. ${ }^{313}$ The first steps were taken by the New York Chamber of Commerce and the New York Bar Association, resulting in the passage of the first arbitration act in the United States. ${ }^{314}$ The federal government quickly followed this movement and enacted the Federal Arbitration Act in 1925, ${ }^{315}$ which is still in force. ${ }^{316}$

Over the years, the popularity of arbitration has provoked the creation of several provider organizations, and motivated professionals from different disciplines to specialize their knowledge and offer their services as neutral arbitrators on a permanent basis. ${ }^{317}$ With the increased popularity of alternative mechanisms and the growing interest in negotiation and problem solving skills during recent years, many of the organizations have expanded their activities to include mediation and other similar models. ${ }^{318}$

In the particular case of Venezuela, legislation that expressly allowed the use of conciliation and arbitration for civil and commercial disputes can be traced as far back as $1830 .^{319}$ As initially regulated in the Code of Civil

${ }^{311}$ Stephen J. Ware, Arbitration and Assimilation, 77 WASH. U. L.Q. 1053, 1058(2000). The fact that the arbitrators were also members of the community ensured that their determinations were in line with social norms with which the arbitrators were familiar. In addition, the enforcement of the arbitrators' decisions were supported by informal controls that only work well in close-knit communities (e.g., threats of exclusion, ostracism, or other forms of social retaliation against those who violate community norms). $I d$.

${ }^{312}$ Barak D. Richman, Firms, Courts, and Reputation Mechanisms: Towards a Positive Theory of Private Ordering, 104 CoLuM. L. REv. 2328, 2334-35 (2004).

313 AUERBACH, supra note 21, at 102-05.

314 Katherine V.W. Stone, Private Justice: The LaW of Alternative Dispute RESOLUTION 311 (2000) ("In 1919, the New York Chamber of Commerce joined with the New York Bar Association to draft a Statute for the New York legislature changing the common law rule. The statute, drafted by Julius Cohen, was patterned on the English arbitration law of 1898.").

315 Federal Arbitration Act, 9 U.S.C. $\S \S 1-16(2000)$.

316 STONE, supra note 314 , at 312-13.

317 See, e.g., American Arbitration Association, http://www.adr.org (last visited Mar. 13, 2008); JAMS, http://www.jamsadr.com (last visited Mar. 13, 2008).

${ }^{318}$ Hensler, supra note 282, at 183.

319 CONSTITUCIÓN DEL ESTADO DE VENEZUELA [Constitution of the Venezuelan State] art. 190 (1830) (Venez.) ("The Venezuelans are free to solve their differences through arbitration, even if the trial has been initiated."). In the case of mediation (conciliation) it was originally regulated 
Procedure, arbitration and mediation were formally appended to the judicial process, which allowed for extensive judicial control to take place. ${ }^{320}$ In general, the law provided that the arbitrators could be appointed by the judges, had to decide following legal rules and their awards could be reviewed by the courts in numerous circumstances. ${ }^{321}$ This led arbitration to be perceived by some as a very impractical process and gave rise to frequent criticism. ${ }^{322}$

The 1998 CAA, which is modeled after the United Nations Commission on International Trade Law (UNCITRAL) guidelines, addressed and overcame the apparent obstacles imposed by the Code of Civil Procedure. ${ }^{323}$ Among its innovations, the CAA expressly recognized the importance of providing organizations whose main role was to administer arbitration and mediation procedures, to devise and apply standards and to maintain a roster of neutrals to serve the business community. ${ }^{324}$

Some ADR centers were already in place before the passing of the CAA, but had no activity until after this legislation entered into effect. ${ }^{325}$ The CAA triggered the interest of chambers of commerce in sponsoring institutional providers, two of which began to operate in Caracas: the Business Center for Conciliation and Arbitration (CEDCA) sponsored by the VenezuelanAmerican Chamber of Commerce (VENAMCHAM), ${ }^{326}$ and the Arbitration Center of the Caracas Chamber of Commerce (CACCC). ${ }^{327}$ The other ADR center, the Arbitration Center of the Maracaibo's Chamber of Commerce (CCM), opened its doors in the city of Maracaibo, one of the most important business hubs in the country. ${ }^{328}$

in the Venezuelan Code of Civil Procedure of 1836. Codigo de Procedimiento Judicial [Code of Civil Procedure] arts. 12-13 (1836) (Venez.). In other Latin American countries, the experience is similar.

${ }^{320}$ See Gómez, supra note 156.

321 Id. at 21.

322 Id. at 33 .

323 Id. at 45.

${ }^{324}$ Ley de Arbitraje Comercial [Commercial Arbitration Act] arts. 11-14 (1998) (Venez.).

${ }^{325}$ Interview with Luis Cova Arria, Cova Arria \& Asociados, in Caracas, Venezuela (Aug. 2, 2001); Interview with Diana Droulers, Director Arbitration Center of the Caracas Chamber of Commerce, in Caracas, Venezuela (Aug. 3, 2001).

${ }^{326}$ See CEDCA, http://www.cedca.org.ve/cedca-ingles/red_cost.htm (last visited Mar. 13, 2008).

327 The CACCC started its activities in 1998, and the first case was decided on that same year. See Centro de Arbitraje, http://www.arbitrajeccc.org (follow “Quiénes Somos” hyperlink to "Misión Vision") (last visited Mar. 13, 2008).

${ }^{328}$ CONAPRI, LAS CIUDADES MÁS ATRACTIVAS PARA INVERTIR 75 (2005), available at http:// 
All three centers have more or less the same structure and are similarly sponsored by business associations (chambers of commerce), which not only provide financial support but also facilities and necessary equipment. ${ }^{329}$ All centers offer both arbitration and mediation (conciliation) services, but they all appear to be more focused on the former. CEDCA and CACCC have adopted procedural rules and ethical standards for mediators and arbitrators. ${ }^{330}$ Each center also has permanent staff members, and a budget to operate and maintain a permanent roster of neutrals. ${ }^{331}$

Many lawyers appear in the list of both centers, which is regarded as prestigious within the business community. ${ }^{332}$ Inclusion in the arbitrator's list seems to be driven more by the idea of social contacts than by the candidate's skills or previous experience with $\mathrm{ADR}^{333}$ One might think that the fact that most, if not all, roster members are currently practicing attorneys instead of full-time neutrals would create conflicts of interest in the relatively small Venezuelan business community; nonetheless, it is instead viewed as an advantage, ${ }^{334}$ as the connections and social status of the arbitrators within the lawyers' community are precisely what makes them valuable in the eyes of local businesspeople. ${ }^{335}$

www.conapri.org/download/Ciudades.pdf.

329 See Gómez, supra note 292.

${ }^{330} \mathrm{Id}$.

${ }^{331} I d$.

${ }^{332}$ See Interview with business lawyer, Partner at International Law Firm, in Caracas, Venezuela (June 19, 2003) [hereinafter Interview \#21]; Interview with business lawyer, in Caracas, Venezuela (June 22, 2003) [hereinafter Interview \#23]; Interview \#44, supra note 233; Interview \#40, supra note 202.

${ }^{333}$ According to CEDCA's rules, for instance, in order to be included in the list of neutrals, the aspirants have to be "invited" by the Board to submit a written request accompanied by two references, and his or her resume. See CEDCA, Rules of Conciliation and Arbitration, ch. 1, arts. 3.2-3.3, available at http://www.cedca.org.ve/cedca-ingles/rules.htm (last visited Mar. 13, 2008). It is expressly indicated that the Board will take into consideration "their reputation, experience, interest and availability to serve." $I d$. art. 3.2. The rules also indicate that an "application may be rejected even though [the candidate] enjoy[s] a recognized professional career," which gives certain leeway to reject those who are not members of the network. Id. art. 3.3(a).

${ }^{334}$ See CEDCA, Forward to the Rules of Conciliation and Arbitration, available at http:// www.cedca.org.ve/cedca-ingles/code.htm (last visited Mar. 18, 2008).

${ }^{335}$ See Gómez, supra note 164. 
In general terms, these private centers are viewed as positive within the business community. ${ }^{336}$ Most of the interviewees agreed that both CEDCA and CACCC were well regarded, and are widely supported. However, very few people actually use their services as can be seen in the following table that shows the usage rate (decided arbitration cases) for the three main centers during the years of 2001-2005:

\section{USE OF PRIVATE INSTITUTIONALIZED ADR IN VENEZUELA (2001-2005) $)^{337}$}

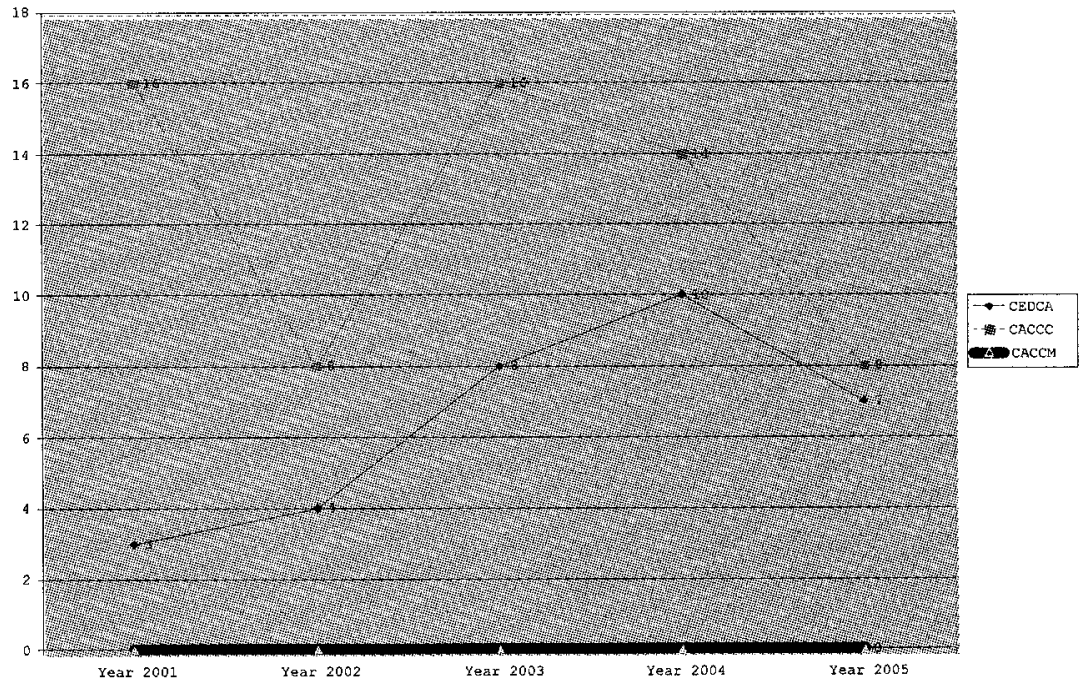

Even though the actual number of business disputes that could go to arbitration or mediation in the first place is not known, it is fair to say that private ADR institutions handle very few cases. Actual usage is not even consistent with the estimate of the centers' representatives, who initially predicted that in the beginning, ADR institutions would resolve $85 \%$ of the

336 See Interview with business lawyer, head of Litigation Practice, in Caracas, Venezuela (June 18, 2003); Interview \#21, supra note 332; Interview \#23, supra note 332; Interview \#40, supra note 202; Interview \#44, supra note 233.

337 See CACCC, http://www.arbitrajeccc.org/info general.html (last visited June 20, 2006). The table reproduced above is no longer available online and is on file with the author. For similar data see Número de Casos: CACC 1998-2007, http://www.arbitrajeccc.org/editor/deta iltemplate.asp?item_id=159 (last visited Mar. 15, 2008). 
controversies among corporate parties, and also that disputants would widely use the centers in order to avoid the corrupt, slow and costly courts. ${ }^{338}$

\section{Thanks, But No Thanks}

Notwithstanding the enormous efforts and resources invested, and the apparent positive image that ADR centers have among members of the business community, these institutions have not been truly embraced by its potential beneficiaries. ${ }^{339}$ Instead, disputants continue to prefer processing their conflicts in the same traditional ways that have always been available to them, and, consequently, the new ADR centers are still among the least used paths. $^{340}$

With very few exceptions, the executives and corporate lawyers interviewed had a positive image of mediation and arbitration, and were generally in favor of its promotion. Indeed, the private sector has offered financial and institutional support to the new arbitration centers. ${ }^{341}$ At the time of the interviews, many business executives-mainly from multinational corporations - were also familiar with ADR processes and had been trained in negotiation and problem solving techniques. Business lawyers, on the other hand, were not only acquainted with the legal framework of arbitration and mediation but in many cases had attended ADR workshops and were knowledgeable about the leading literature in the field. Interestingly, they also reported using mediation very often.

However, the mediation that most of these lawyers and executives employ is not the one offered by the ADR centers in an institutionalized form. The mediation they reported using often takes place after golf or tennis matches at the local country club, during dinner parties, weddings and other social engagements. Prominent lawyers whom both parties respect and know well tend to act as neutrals. ${ }^{342}$ These lawyers are practicing attorneys from the

${ }^{338}$ See Leon, supra note 299.

339 See Gómez, supra note 164 , at 6.

${ }^{340}$ This is not difficult to foresee given the distinctive features of the Venezuelan society in general, and the business sector in particular, where it is very common for participants to be mutually bound by multiplex relationships and to be part of a relatively dense social network.

${ }^{341}$ See Gómez, supra note 156.

${ }^{342}$ The fact that these mediators are members of the same community to which the parties belong, and therefore have a corresponding relationship with them, is what determines their greater intervention (process and decision control). In addition, they are chosen to intervene as 
leading law firms, and as such, also belong to networks that give them access to certain spheres of influence within the business sector. Their names are always included in the rosters of the ADR centers, but interestingly, it is not through these institutions that they get referrals.

Even though businesspeople have shown support to the new ADR providing institutions, it seems obvious that they have little incentive to use their services. $^{343}$ As one business lawyer told us:

Why would I recommend my clients to use CEDCA and pay an expensive administrative fee if I can simply reach the same arbitrators or mediators through another way? I have known most of these guys (arbitrators) since law school days, we are members of the same social clubs, our kids go to the same schools and even our firms are relatively close to each other; I can just call them anytime and sort things out without the hassle and the cost of going through the centers. ${ }^{344}$

This opinion seemed to be shared by several others who operate in the same social circles.

third parties to a dispute because of their perceived higher social status, but more importantly, because others have trust in them. For a detailed study about trust and its effect on social structures, see KAREN S. COOK ET AL., COOPERATION WITHOUT TRUST? 2 (2005). However, the trade-off is that these mediators are not really neutral in the sense that, as members of the same community, they are subject to its social norms and may also have an interest that collides with one (or both) of the parties. Most of the interviewees seemed to acknowledge this tension and generally considered it to be outweighed by the fact that disputes were dealt with within the community "among people like them." See Interview \#45, supra note 276.

${ }^{343}$ The scant use of voluntary ADR processes has also been explored by Merry \& Silbey, who in turn suggested that, in general:

citizens do not use alternatives voluntarily to the extent hoped for by proponents of ADRMs because by the time a conflict is serious enough to warrant an outsider's intervention, disputants do not want what alternatives have to offer (. . .) At this point they conceptualize their problem as a principled grievance for which they seek an authoritative and binding solution, not as a conflict of interest in which they have limited and negotiable goals.

Merry \& Silbey, supra note 60, at 154.

344 Interview with Venezuelan business lawyer, litigation department in international law firm, in Caracas, Venezuela (Jan. 31, 2005). 
As previously explained, the Venezuelan business sector is a relatively small and cohesive community in which many members know each other and are bound together by multiplex relationships. Aside from the typical economic or business interests that characterize the links that exist between members of this community, many of these members are also tied together by kinship, or lifelong friendships. As a result, when disputes arise among community members who are bound by multiplex, and permanent social ties, the parties prefer to use processes that not only help them to resolve the issue at hand, but that also contribute to preserve their social bonds and have the least negative impact on their environment. Intra-group conciliatory mechanisms (non-institutionalized mediation) fit easily into that category.

Mediation seems to be a preferred mechanism among business disputants in Venezuela, but only when it is used in an environment that preserves the participants' social values and their identity as a group. ${ }^{345}$ This is only possible when done within the realm of their social networks, and therefore, outside the formal institutions (ADR centers). ${ }^{346}$

$\mathrm{ADR}$ centers were originally promoted by reform advocates with the idea of offering efficient alternatives to the courts, which in their view were unattractive to business disputants. ${ }^{347}$ The vision was to make institutionalized ADR processes available to the entire business community, but they failed to take into account that these centers would not fulfill any need. ${ }^{348}$ As previously described, business lawyers and their clients are already satisfied with the traditional way of processing disputes and even if they believe that $\mathrm{ADR}$ centers are a good idea, at least for now, they have chosen to decline using it.

\section{CONCLUSION}

Almost two decades after the implementation of judicial reform agendas throughout Latin America, scholars and reform advocates are still debating why many reform policies have failed in the region, and why institutionalized

${ }^{345}$ See Gómez, supra note 156.

${ }^{346}$ Id.

${ }^{347}$ Id.

${ }^{348}$ Id. 
ADR processes have been so timidly received by Latin American business disputants, contrary to the proponents' initial prediction. ${ }^{349}$

In order to understand the reasons for these phenomena, scholars have increasingly proposed the need for empirical research, but not much has been done in that respect. ${ }^{350}$ To a certain extent, this Article has attempted to fill that gap.

The present study showed that business disputants in Venezuela have access to a variety of alternatives for processing their legal conflicts. As shown, these alternatives operate on different levels, ranging from the official fora that typically host formal mechanisms (i.e., trial in courts) to the noninstitutionalized environments of informal processes (i.e., mediation outside ADR centers).

Furthermore, this research has revealed that individual choices for dispute processing are heavily influenced by the social environment, and not simply influenced by the factors commonly portrayed in traditional scholarly literature, which views disputes as "disembodied events separated from the social world" and not as a cultural behavior. ${ }^{351}$

Traditional scholarly approaches have focused on the functioning of official institutions and the processes that take place within them, without taking into account the larger social context. ${ }^{352}$ These paradigms have also described societies and their legal systems in terms of an artificial dichotomy that labels them as traditional or modern. ${ }^{353}$ As none of these approaches have acknowledged the importance of social interactions and the ways in which individual behavior is affected by the social context, researchers have been able to obtain only a partial view of how institutions and social processes operate. ${ }^{354}$

Legal and judicial reform advocates, for example, have traditionally looked at dispute resolution processes through the narrow lens of state-sponsored institutions and the mechanisms that typically take place within them, therefore

${ }^{349}$ Id.

${ }^{350}$ Messick, supra note 54.

351 Merry, supra note 29, at 2063.

352 See supra Part III.

${ }^{393}$ Id.

${ }^{354}$ Id. It could be argued, however, that the new legal pluralism paradigm constitutes an exception because it not only looks at the social interactions, but also at the "unofficial forms of ordering located in social networks or institutions." Merry, supra note 22, at 869, 873. 
reaffirming the centralistic approach that has characterized traditional legal scholarship for many years. ${ }^{355}$ Most reform agendas have focused on strengthening official institutions, and the processes that take place within them, and have largely disregarded the dynamics that occur outside such formal institutions. ${ }^{356}$

Socio-legal scholars have usually paid most of their attention to the dispute resolution processes that take place within the courts, in spite of the fact that the majority of business disputes are not channeled through these official fora. ${ }^{357}$ Few conflicts are actually brought into the judicial process; only a fraction of these reach the stage of formal decision or judgment, ${ }^{358}$ and an even smaller number of disputes are actually resolved. ${ }^{359}$ As in many other legal systems, the majority of business disputes are not brought into the Venezuelan courts, as parties do not view the courts as their first option. ${ }^{360}$ Nonetheless, as stated above, reform advocates seem to have an entirely different picture.

In the specific case of Venezuela, by being entrenched in such a courtcentered approach, reformers and ADR advocates overlooked important procedural choices that business disputants often make preventing them from achieving an accurate assessment. ${ }^{361}$ Also, reformers acted on the basis of several assumptions that were far from being proven. ${ }^{362}$

This Article recognizes that the context in which disputants interact and the social relationships that connect them with other social actors exert an important influence on how they decide to process their legal disputes through the various formal and informal mechanisms.

As this research demonstrated, the decision to use a particular mechanism (formal vs. informal) or procedural approach (adjudicatory vs. conciliatory, dyadic vs. triadic) depends on the social context, and not necessarily on the

${ }^{355}$ Galanter, supra note 20, at 20-21. However, more recently, we have witnessed a surge of scholarly work related to the idea of private ordering, thus offering a more ample view about which processes disputants use and why. Id.

${ }^{356}$ HUGO EYZAGUIRRE, INTER-AM. DEV. BANK, INSTITUTIONS ANDECONOMIC DEVELOPMENT: JUDICIAL REFORMINLATIN AMERICA (Feb. 1996), available at http://www.iadb.org/sds/doc/sgcDoc12-E.pdf.

${ }^{357}$ Galanter, supra note 20, at 20.

358 Id. at 3.

359 Here, "resolved" means that both parties reach any form of closure.

${ }^{360}$ See Gómez, supra note 156.

${ }^{361}$ Id.

${ }^{362}$ See Gómez, supra note 56. 
intrinsic characteristics of each mechanism. Venezuelan lawyers, for example, do not use judicial processes because of their intrinsic value as impartial adjudicatory mechanisms, but rather because they occur in a forum where disputants feel comfortable. By the same token, business disputants seem to use ADR processes not because of ADR's ability to ensure distributive justice, but instead, because it takes place in a familiar social context. In other words, the choice of mechanisms follows from the perceived advantages of the forum to those who actually use it.

Additionally, by going beyond the artificial dichotomy fashioned by traditional scholars to describe societies and their legal systems, the social networks' paradigm has allowed me to describe dispute processing choices in an environment that combines many features that are typically seen in technologically advanced, modern and affluent societies, and at the same time, some of the characteristics that socio-legal scholars attribute to societies considered to be indigenous or traditional.

Dispute processing among Venezuelan business actors takes place in a context where interpersonal relations are paramount and social networks have permeated private and public institutions. This characteristic has allowed social networks to become stronger and to maintain a leading role in the operation of the business sector. It has also strongly influenced the way in which its members process their disputes.

As stated above, social networks are often used for processing disputes outside state institutions. However, from time to time, people need the intervention of courts or other state-sponsored agencies which, interestingly, also rely on the intervention of social networks.

The two examples offered in this Article of procedures and procedural choices embedded within the larger case study of the Venezuelan business sector demonstrate how disputants' choices are heavily influenced by the social context in which they interact.

In the first place, the research demonstrates how reliance on social networks drives business parties in Venezuela to use the courts voluntarily in spite of the conventional wisdom-among judicial reform advocates-that disputants avoid using the judiciary at all costs. Second, the research demonstrates how social networks are also relied upon for mediating and arbitrating disputes that arise among businesspeople and paradoxically, how this has discouraged potential use of the recently established ADR centers. 
Although this project focused on the Venezuelan business sector, it has broader implications. The social networks paradigm has offered a way to explore the ways in which individuals cope with interpersonal conflict within social group settings, to understand the ways in which group norms are effectively enforced in the absence of a centralized formal authority; but most importantly, to explain the influence of the social context on individual choices for dispute processing mechanisms and fora, in a way that goes beyond the dichotomy that views societies as either traditional or modern. ${ }^{363}$ Ultimately, this analysis also helps scholars understand the role of conflict in the transformation and maintenance of social structures.

${ }^{363}$ See Mitchell, supra note 74, at 8-9; see supra note 120 and accompanying text. 